\title{
TRADE CREATION AND DIVERSION REVISITED: ACCOUNTING FOR MODEL UNCERTAINTY AND NATURAL TRADING PARTNER EFFECTS
}

\author{
THEO S. EICHER, ${ }^{a *}$ CHRISTIAN HENN ${ }^{\mathrm{b}}$ AND CHRIS PAPAGEORGIOU ${ }^{\mathrm{b}}$ \\ a Department of Economics, University of Washington, Seattle, WA, USA \\ ${ }^{\mathrm{b}}$ International Monetary Fund, Washington, DC, USA
}

\begin{abstract}
SUMMARY
The effect of preferential trade agreements (PTAs) on trade flows is subject to model uncertainty stemming from the diverse and even contradictory effects suggested by the theoretical PTA literature. The existing empirical literature has produced remarkably disparate results and the wide variety of empirical approaches reflects the uncertainty about the 'correct' set of explanatory variables that ought to be included in the analysis. To account for the model uncertainty that surrounds the validity of the competing PTA theories, we introduce Bayesian model averaging (BMA) to the PTA literature. Statistical theory shows that BMA successfully incorporates model uncertainty in linear regression analysis by minimizing the mean squared error, and by generating predictive distributions with optimal predictive performance. Once model uncertainty is addressed as part of the empirical strategy, we find strong evidence of trade creation, trade diversion, and open bloc effects. Our results are robust to a range of alternative empirical specifications proposed by the recent PTA literature. Copyright (c) 2010 John Wiley \& Sons, Ltd.
\end{abstract}

Received 9 January 2008; Revised 20 April 2010

\section{INTRODUCTION}

Bhagwati and Panagariya (1996) call preferential trading arrangements (PTAs) 'two faced' because PTAs introduce trade liberalization at the cost of discrimination. The controversy regarding the costs and benefits of PTAs has raged since the 1950s, due to the potential for trade creation and trade diversion (Viner, 1950). Time has not provided a consensus; to the contrary, with the proliferation of PTAs in the 1990s, the number of PTA theories that predict either increasing or decreasing trade flows among (non-)members increased in tandem. And as the number of theories expanded, the set of candidate regressors suggested by empirical PTA research approached the point where comprehensive robustness has become virtually unfeasible. Consequently, it has become common practice in this literature to juxtapose results that represent alternative PTA theories. It is therefore not surprising that PTA coefficient estimates have been found to be highly sensitive to the specific set of regressors used in any given study (see Baxter and Kouparitsas, 2006).

Ghosh and Yamarik (2004) provide the most extensive PTA robustness analysis to date. Not only do they include a large set of PTAs, but they also employ extreme bound analysis (Leamer, 1983) to examine a diverse set of PTA theories. Ghosh and Yamarik (2004) find little evidence for either trade-creating or trade-diverting PTAs. They conclude that 'the pervasive trade creation effect found in the literature reflects not the information content of the data but rather the unacknowledged beliefs of the researchers'.

* Correspondence to: Theo S. Eicher, Department of Economics, Box 353330, University of Washington, Seattle, WA 98195 USA. E-mail: te@u.washington.edu

Copyright (c) 2010 John Wiley \& Sons, Ltd. 
In this paper we apply Bayesian model averaging (BMA) to the PTA literature to re-examine model uncertainty. BMA is specifically designed to incorporate model uncertainty into the estimation process and is firmly rooted in statistical theory. It is a methodology that explores the model space without restrictions, weighs each model according to quality, and provides a probability distribution for each coefficient estimate. Raftery and Zheng (2003) show that BMA maximizes predictive performance while minimizing the total error rate when compared to any individual model. The rapidly growing list of economics applications using BMA include policy evaluations (e.g. Brock et al., 2003), monetary policy (e.g. Levin and Williams, 2003), macroeconomic forecasting (e.g. Garratt et al., 2003), economic growth (e.g. Fernandez et al., 2001), and international economics (e.g. Chen and Rogoff, 2006).

The issue of model uncertainty surrounding PTA effects is well known in the PTA literature. Seldom do papers present less than a dozen different PTA regression specifications. We show that BMA overturns the fundamental Ghosh and Yamarik result by identifying a number of PTAs that exert decisive effects on trade flows. Since Ghosh and Yamarik, the PTA literature has evolved to introduce a number of innovations that address omitted variable bias. We show that our main finding of measurable PTA effects on trade flows is robust, even when the Ghosh and Yamarik (2004) dataset is updated to include additional years, additional PTAs, and alternative fixed-effect specifications. ${ }^{1}$ Our methodological extensions include a full account of multilateral resistance (see, for example, Anderson and van Wincoop, 2003; Subramanian and Wei, 2007), bilateral unobserved heterogeneity (see, for example, Glick and Rose, 2002; Egger and Pfaffenmayr, 2003), and an approach to control for both multilateral resistance and heterogeneity simultaneously (Baier and Bergstrand, 2007; Baldwin and Taglioni, 2006). We also consider accession dynamics (Freund and McLaren, 1999). Our analysis follows a voluminous literature spanned by Frankel et al. (1995, 1997), Rose and van Wincoop (2001), Frankel and Rose (2002), and Rose (2004). ${ }^{2}$

Our BMA benchmark specification, using Ghosh and Yamarik's (2004) original dataset, shows strong trade creation, trade diversion, and open bloc effects for 12 PTAs. ${ }^{3}$ Our results are at odds with Ghosh and Yamarik (2004), even if we use their identical dataset. The differences arise for the following two reasons. First, BMA inference is based on an unrestricted search of the model space spanned by all candidate regressors, while extreme bound analysis covers only a fraction of the model space due to the researcher's categorization of variables into 'free' (variables that should always be included in the regression specification) and 'doubtful' (variables that may be effective in the regression specification). Second, BMA theory requires that each model is weighed according to its posterior model probability (which is associated with the model's quality or performance), while extreme bound analysis weighs all models equally and thus attributes the same power of inference to both strong and exceptionally weak models. ${ }^{4}$

Even after we extend the Ghosh and Yamarik data from 1970-1995 to 1960-2000 and include more recent bilateral trade agreements, our results remain robust. In fact, a number of PTAs are estimated with increased precision, which allows us to identify additional trade-creating PTAs. The updated dataset also modifies the counterintuitive trade diversion effects (for NAFTA) and

\footnotetext{
${ }^{1}$ It is important to note that most of the literature has ignored general equilibrium effects and estimates. The primary goal of this paper is to flag more robust estimates of the "partial' or direct effects of PTAs and other controls, in order to provide potentially better inputs for general equilibrium comparative statics.

${ }^{2}$ An appealing alternative is to examine the intensive and extensive margins of trade as proposed by Helpman et al. (2008) and Felbermayr and Kohler (2006). We leave this to future research.

${ }^{3}$ It is common in extreme bound analysis to attach all the weight of the posterior to the prior distribution. While extreme bound analysis provides no guidelines, Ghosh and Yamarik (2004) also examine the case where 95\% of the weight of the posterior distribution is on the prior and $5 \%$ on the sampling distribution - in this case they find trade creation in four PTAs (CACM, CARICOM, MERCOSUR and APEC).

${ }^{4}$ Previous comparisons between extreme bound analysis and BMA results have also found extreme bound analysis to be excessively stringent (see Sala-i-Martin, 1997; Fernandez et al., 2001).
} 
the unexpectedly large open bloc effects (for MERCOSUR) that were implied by the Ghosh and Yamarik data. Controlling for multilateral resistance does not affect our result qualitatively, and the vast majority of PTAs are shown to exert influence on trade flows, mostly through trade creation among member countries.

Our approach to addressing multilateral resistance follows directly from Anderson and van Wincoop (2003) and Novy (2006, 2007), as implemented by Subramanian and Wei (2007), whose context was different and it did not address individual PTA effects. We also show that estimates based on multilateral resistance are generally larger than estimates that account for unobserved country-pair heterogeneity (an approach advocated by Glick and Rose, 2002; Rose, 2004, 2005). This may be due to the methodological difference, whereby country-pair fixed effects render estimates that measure only those PTA effects that are directly related to accession. This raises the question of accession dynamics; we show that PTA trade effects generally appear around accession or thereafter. ${ }^{5}$

Our most comprehensive specification controls simultaneously for multilateral resistance and unobserved heterogeneity among countries. This specification is inspired by Baier and Bergstrand (2007), who produce a similar specification, but without emphasis on the heterogeneous effects that individual PTAs exert on trade flows. Even in this most comprehensive specification, we find strong effects of PTAs on trade flows, for the Andean Pact, Central American Common Market, European Economic Area, Latin American Integration Association, and for bilateral trade agreements.

The remainder of the paper is organized as follows. Section 2 discusses the basic framework of the BMA methodology used in our estimation. In Section 3 we take a look at the datasets employed, and in Section 4 we report and discuss our results. Section 5 concludes.

\section{THE EMPIRICAL FRAMEWORK}

\subsection{Baseline Specification}

Econometric studies that seek to identify the impact of PTAs on trade flows are generally based on the gravity model. ${ }^{6}$ The approach fits the application particularly well, due to the gravity model's proven efficiency in predicting trade flows (see Frankel and Romer, 1999). This allows PTA coefficients to pick up on deviations between predicted and actual trade.

Ghosh and Yamarik (2004) include dummies that capture PTA effects on bilateral trade alongside a matrix of other covariates, $Z_{i j t},{ }^{7}$ obtaining

$$
\log T_{i j t}=\alpha_{t}+\beta_{1} \log Y_{i t} Y_{j t}+\beta_{2} \log D_{i j}+\beta_{3} Z_{i j t}+\beta_{4} \mathrm{PTA}_{i j t}+\beta_{5} \mathrm{PTA}_{i t}+\varepsilon_{i j t}
$$

where average bilateral trade, $T_{i j t}$, between countries $i$ and $j$ at time $t$ depends positively on national incomes, $Y_{i t}$ and $Y_{j t}$, and negatively on bilateral distance, $D_{i j}$. The matrix of other covariates, $Z_{i j t}$, is included to represent alternative trade theories and to proxy for unobservable trade costs. The inclusion of time fixed effects, $\alpha_{t}$, is standard in the literature to eliminate bias resulting from aggregate shocks to world trade, such as global income shocks. Time fixed effects

\footnotetext{
${ }^{5}$ The accession dynamics results are interesting in light of the emerging 'endogenous PTA' strand of literature (Baier and Bergstrand, 2007). This paper does not address endogeneity explicitly, although regressors used to control for endogeneity by Baier and Bergstrand (2007) are included here. We discuss endogeneity bias later on. Similarly, while we are unable to prove that our specifications are free of omitted variable bias, our expanded dataset is one of the most comprehensive to date.

${ }^{6}$ The theoretical foundations of the gravity model are presented in Frankel (1997) and Deardorff (1998).

${ }^{7}$ The set of specific correlates used is discussed in Section 2.3.
} 
also mitigate any spurious correlation introduced, for example, by the use of a US price index to deflate all trade flows. To capture PTA effects, two sets of zero-one dummy variables are included for each time interval, $t$. PTA $i j t$ indicates that both trading partners are members of the same PTA in a given year, and $\mathrm{PTA}_{i t}$ indicates that only one member has joined. These dummies enable us to isolate the three distinct effects that PTAs may exert on trade flows. A positive coefficient on $\mathrm{PTA}_{i j t}$ captures trade creation among PTA members, while trade diversion registers a negative PTA $_{i t}$ coefficient. Finally, open bloc trade creation is simply the opposite of trade diversion, characterized by a positive PTA $_{i t}$ coefficient.

\subsection{Multilateral Resistance and Unobserved Heterogeneity}

Equation (1) can be extended to control for multilateral resistance and unobserved country-pair heterogeneity. In place of average trade, multilateral resistance requires the use of either bilateral imports (Subramanian and Wei, 2007) or bilateral exports (Novy 2006, 2007) as the dependent variable. ${ }^{8}$ Here we largely follow Subramanian and Wei (2007) to generate results that are comparable to their benchmark:

$$
\log \left(\operatorname{Imports}_{i j t}\right)=\alpha_{t}+\alpha_{i t}+\alpha_{j t}+\beta_{2} \log D_{i j}+\beta_{3} \tilde{Z}_{i j t}+\beta_{4} P T A_{i j t}+\varepsilon_{i j t}
$$

The added advantage of using bilateral imports, Imports $_{i j t}$, as the dependent variable is that it avoids bias induced from averaging trade flows (see Baldwin and Taglioni, 2006). ${ }^{9}$ Since any nation faces only one import/export price index at any point in time, multilateral resistance can be accounted for with time-varying importer/exporter fixed effects (represented by $\alpha_{i t}$ and $\alpha_{j t}$ ). ${ }^{10}$ The inclusion of time-varying importer/exporter effects does not allow for average trade flows as the dependent variable and we follow Subramanian and Wei (2007) and choose bilateral imports instead. Multilateral resistance controls in (2) absorb some of the covariates, which reduces $Z_{i j t}$ to $\tilde{Z}_{i j t}$. Most notably the remoteness measure is now absorbed. Remoteness speaks only to GDPweighted geographic distance, which changes only slightly over time because the GDP weights are time-varying (see Section 2.3). Multilateral resistance, instead, also accounts for variations in prices of all trading partners over time, which can imply considerable fluctuations.

In addition, multicollinearity no longer allows for the identification of separate trade creation and diversion effects. In the presence of time-varying importer effects, the $\mathrm{PTA}_{i j t}$ dummy partitions an importer's observations in any given year into (a) imports originating from fellow PTA members and (b) imports from non-members. As a consequence, the PTA $_{i j t}$ dummies now express net trade creation, or how much greater intra-PTA trade is compared to trade between PTA members and non-members. This implies that when trade between members and non-members decreases because of trade diversion, the $\mathrm{PTA}_{i j t}$ coefficient increases in this specification.

Unobserved country-pair heterogeneity can be addressed by controlling for all time-invariant bilateral heterogeneity with country-pair fixed effects, $\alpha_{i j}$, as follows:

$$
\log \left(\operatorname{Imports}_{i j t}\right)=\alpha_{t}+\alpha_{i j}+\beta_{1} \log Y_{i t} Y_{j t}+\beta_{3} \bar{Z}_{i j t}+\beta_{4} \mathrm{PTA}_{i j t}+\varepsilon_{i j t}
$$

\footnotetext{
${ }^{8}$ Some argue that this is advantageous, since trade theories yield predictions on unidirectional trade (see Freund, 2000; Anderson and van Wincoop, 2003; Baldwin and Taglioni, 2006).

${ }^{9}$ Alternative estimation approaches can also address measurement error bias (see Felbermayr and Kohler, 2006; Santos Silva and Tenreyro, 2006).

${ }^{10}$ Time-varying importer/exporter fixed effects are lucidly motivated by Baldwin and Taglioni (2006).
} 
Note that now all time-invariant regressors are absorbed into the pair-specific fixed effects. ${ }^{11}$ Pair fixed effects capture similarities of trading partners that are constant over time. With these pair-specific constants, our regression only relies on time series variation, comparing each country pair's observations before and after PTA accession to determine the $\mathrm{PTA}_{i j t}$ coefficient. Therefore here, as in equation (1), PTA $_{i j t}$ expresses only intra-PTA trade creation. The country-pair fixedeffect specification, together with Rose's remoteness variable to (imperfectly) capture multilateral resistance, represents a general formulation of the gravity equation to address unobserved heterogeneity (e.g. Egger, 2000; Baldwin, 2005). If country-pair fixed effects are omitted, the PTA coefficients tend to be biased upward because they pick up trade creation that is not specifically PTA related, but simply due to unobservables. The introduction of country-pair fixed effects absorbs non-time-varying control variables, which reduces the original matrix of other covariates to $\bar{Z}_{i j t}$ (in equation (3)) to $\tilde{Z}_{i j t}$ (in equation (2)).

The most comprehensive approach to controlling for unobserved heterogeneity, multilateral resistance, and all other unobserved time-varying importer and exporter specific effects, is to combine (2) and (3). This yields a specification that is most likely to generate unbiased coefficient estimates, while adhering to theoretical foundations. This specification was suggested by Baier and Bergstrand (2007) in the context of estimating average trade effects across all PTA member countries. It can be obtained by adding country-pair $(i j)$ fixed effects along with the time-varying importer/exporter $(i t, j t)$ fixed effects to equation (1): ${ }^{12}$

$$
\log \left(\operatorname{Imports}_{i j t}\right)=\alpha_{i j}+\alpha_{i t}+\alpha_{j t}+\beta_{2} \log D_{i j}+\beta_{3} \tilde{Z}_{i j t}+\beta_{4} P T A_{i j t}+\varepsilon_{i j t}
$$

Baier and Bergstrand (2007) also point out that in panel data fixed effects or first differencing can be employed to address some of the potential endogeneity in the PTA regressions. ${ }^{13}$ The fixed effects in equations (2) -(4) can partially address two out of three sources of endogeneity bias. The first type of endogeneity bias may arise in equation (1) between GDP and trade flows (see Frankel and Romer, 1999). The inclusion of time-varying importer/exporter fixed effects will contain this source of bias. The second type of bias arises due to the endogeneity between trade flows and trade policies. Trefler (1993) first used instruments to addess the endogeneity of trade policies and found the effect of such policies to increase tenfold. Lee and Swagel (1997) also document that the effect of trade liberalization on imports is biased downward in the absence of instrumenting for endogeneity.

The third source of possible endogeneity is that countries might endogenously select into (specific) PTAs. This bias is less likely addressed by fixed effects. Baier and Bergstrand (2004a) find cross-section evidence that country pairs with common economic characteristics also tend to share PTA memberships. Baier and Bergstrand (2007) suggest that the endogeneity of PTA membership likely renders the PTA coefficient biased downward in cross-sections. ${ }^{14}$

\footnotetext{
${ }^{11}$ We estimate equations (1) using the Andrews et al. (2006) 'FEiLSDVj' estimator, which relies on partitioned regression techniques to reduce computational burden; it delivers identical results to LSDV regressions.

12 The alternative would be to first-difference. Wooldridge (2002, Ch. 10) shows that when the number of time periods exceeds two, the fixed-effects estimator is more efficient under the assumption of serially uncorrelated error terms. Baier and Bergstrand (2007) provide a comprehensive discussion of the two approaches whose results might differ slightly depending on the length of the panel and the structure of the error terms. Although both approaches have advantages and disadvantages, Baier and Bergstrand show in a panel that is basically identical in error structure to ours that the results are very similar. Hence we present the fixed-effects results below.

${ }^{13}$ Aside from Baier and Bergstrand (2007), the potential PTA endogeneity bias in cross-section gravity models is also addressed by Baier and Bergstrand (2002, 2004b) and Magee (2003), but with mixed success. Baier and Bergstrand (2007) also lament that 'other methods to identify the impact, such as instrumental variables using cross-section data, are compromised by a lack of suitable instruments'.

${ }^{14}$ To paraphrase, their reasoning is that PTA membership of a trading pair and the intensity of their domestic regulations may be positively correlated in a cross-section of data, but the gravity equation's error term and the intensity of domestic 
They argue that a key source of this endogeneity may be bilateral unobserved characteristics, for example, common institutions or regulations. Such unobserved bilateral characteristics may be the determinants of countries' trade and of their PTA membership decisions. In this case the endogeneity bias would be largely cross-sectional in nature, and it can be controlled by the country-pair fixed effects that we include in our panel regressions.

Egger (2004) argues that the estimates obtained in the regressions above may be biased downward if there exist cross-section dependencies that result in correlations between explanatory variables and unobserved bilateral effects exists. Thus he proposes the Hausman and Taylor (1981) two-stage least squares error components model. Serlenga and Shin (2007) incorporate the Egger methodology into the correlated common effect pooled (CCEP) estimation approach, which was advanced by Pesaran (2006). Serlenga and Shin (2007) highlight that the bias can go either way, depending on the specific coefficient estimate and time period examined. This is not surprising since the exact bias depends on the specific correlation structure. Unfortunately, the methods developed by Hausman and Taylor (1981), Pesaran (2006), and Serlenga and Shin (2007) are not available for BMA. Thankfully, however, this type of bias is not of crucial importance in our application since we focus primarily on the coefficients of the time-varying PTA dummies (which are still estimated consistently) and not on the magnitude of time-invariant regressors (such as distance).

Serlenga and Shin (2007) further show that the gravity equation may be biased due to possible cross-section dependence arising from unobserved (heterogeneous) time-specific factors. The authors thus adopt an alternative estimator, originally proposed by Pesaran (2006), to explicitly address such dependencies. The Pesaran estimator has not been implemented in a BMA context; hence we limit ourselves to the approaches that we introduced above. While we are mindful of this bias, we nevertheless regard it as important to consider results that have been obtained via a principled approach to model uncertainty. If anything, the previous literature seems to suggest that the derived estimates are generally too low.

Another bias may arise due to spatial heterogeneity (structural instability or heteroskedasticity; see Anselin and Griffith, 1988). This may lead to biased parameter estimates or misleading significance levels. Bougheas et al. (2003) explore the spatially autocorrelated error terms and use instrumental variables in an attempt to address the issue. Their results show the bias can go either way, depending on the application. Baltagi et al. (2007) also highlight the importance of spatial autoregressive error processes that apply to both the individual and remainder error components. They suggest a maximum likelihood estimator for a general spatial panel with random effects. Here we presume, consistent with previous literature, that the fixed-effects model is predominant for our trade application.

\subsection{Model Uncertainty in PTA Theory}

A voluminous theoretical literature discusses appropriate controls in gravity models, which include proxies for geography, history, economic policy, and development and factor endowments. Each control is motivated by a particular theory. At times the same control is claimed for different theories (with the opposite sign), underlining the rampant model uncertainty. Below we provide a brief description of the theoretical underpinnings of the various controls suggested by the previous literature. It is crucial to outline this diversity of approaches to justify the use of the model averaging methodology.

regulations may be negatively correlated. Hence the $\mathrm{PTA}_{i j t}$ dummies and the error term are negatively correlated, and the PTA coefficient will tend to be underestimated. 
Table I summarizes the extent of the model uncertainty by tabulating the covariates suggested by earlier studies. It highlights the numerous attempts to identify determinants of trade flows and the associated diversity of results. The table shows how important it is to incorportate the model uncertainty that is inherent in gravity/PTA regressions as part of the empirical strategy. When the uncertainty about the true specification is not accounted for in the econometric method, the precision of estimates is inflated, since they neglect the uncertainty surrounding the true theory.

It is important to outline the theoretical backbone for each covariate included in the analysis. Without theoretical support, the results are difficult to interpret. The first set of control variables captures historical ties, such as Common Language, Common Colonizer, or Colony. These covariates are commonly included to capture transaction costs due to communication and/or cultural differences. ${ }^{15}$ Common historical ties lead to similar institutions and similar levels of development, implying reliable contractual and legal standards, as well as trust in shared values. Controlling for model uncertainty addresses not only which one of these regressors (or regressor combinations) is appropriate, but also whether their inclusion is indeed approximating the true model.

Geographic factors have been introduced as proxies for transport costs (e.g. Aitken, 1973), trade-and-geography theories (e.g. Helpman and Krugman, 1985), or New Trade Theories (e.g. Rivera-Batiz and Romer, 1991). Remoteness (developed by Rose, 2000) is the GDP-weighted negative of distance that is often included to capture the notion that relatively remote country pairs are expected to trade more, because they have fewer options in choosing trade partners. ${ }^{16}$ It has also been motivated as a proxy for multilateral resistance, or the average trade costs facing a country (Carrere, 2006). Land Area is intended to capture self-sufficiency and scale effects that are prominent in both the new trade and growth theories (e.g. Rose, 2000; Rose and van Wincoop, 2001). Scale effects are also proxies for technology or knowledge spillovers (e.g. Grossman and Helpman, 1991).

Alternative proxies in the geography category, such as Border, Landlocked, and Island, have previously been utilized by a variety of authors, although it is not immediately clear why adjacency should matter after having controlled for distance. ${ }^{17}$ Perhaps variables that measure distance center-to-center introduce errors that are mitigated by the additional controls, because neighboring countries often engage in large volumes of trade. BMA addresses the uncertainty surrounding the inclusion of geography variables by indicating which covariates are relevant to explaining how PTAs influence trade patterns.

Covariates for development and factor endowments juxtapose the Heckscher-Ohlin factor endowments trade theory with Linder's (1961) hypothesis, which holds that similar countries should trade more because of their similar tastes. Davis (1995) presents an augmented Heckscher-Ohlin-Ricardo model that provides support for either theory, depending on the technological distance between the countries, and Spilimbergo and Stein (1998) examine the issue empirically. Common proxies for factor endowment differences are based on Per Capita GDP, Schooling, and Population Density. ${ }^{18}$ The theoretical rationale for Per Capita GDP is based on the strategic trade literature (e.g. Helpman and Krugman, 1985), which predicts intra-industry trade to increase as countries become more similar in their levels of development. Furthermore, countries with higher per capita GDP are likely to have better access to less distortionary revenue sources. Hence they may experience more bilateral trade since they can afford lower tariffs.

\footnotetext{
${ }^{15}$ See Wei (1996); Frankel (1997); Rose (2000); Soloaga and Winters (2001); Rose and van Wincoop (2001); Frankel and Rose (2002).

${ }^{16}$ See Wei (1996); Rose (2000); Soloaga and Winters (2001); Baier and Bergstrand (2007).

${ }^{17}$ See Frankel and Romer (1999); Rose (2000); Feenstra et al. (2001); Rose and van Wincoop (2001); Soloaga and Winters (2001); Frankel and Rose (2002).

18 They have been introduced by Frankel (1992, 1997), Frankel and Wei (1993), Frankel et al. (1995), Freund (2000), Rose and van Wincoop (2001), and Frankel and Rose (2002).
} 
Table I. Relationship between gravity model controls and bilateral trade in past studies

\begin{tabular}{|c|c|c|c|c|}
\hline & & \multicolumn{3}{|c|}{ Relationship in past studies } \\
\hline & & Positive & None & Negative \\
\hline Trade creation $0-1$ dummies & $\begin{array}{l}\text {AFTA }_{i j} \\
\text {ANZCERTA }_{i j} \\
\text { APEC }_{i j} \\
A P_{i j} \\
\text { CACM }_{i j} \\
\text { CARICOM }_{i j} \\
E_{i j} \\
E F T A_{i j} \\
E U_{i j} \\
\text { LAIA }_{i j} \\
\text { MERCOSUR }_{i j} \\
\text { NAFTA }_{i j}\end{array}$ & $\begin{array}{l}3 \\
1 \\
3 \\
3 \\
4\end{array}$ & $\begin{array}{l}5 \\
9 \\
2 \\
3 \\
3\end{array}$ & \\
\hline Trade diversion/open bloc $0-1$ dummies & $\begin{array}{l}\text { AFTA }_{i} \\
\text { ANZCERTA }_{i} \\
\text { APEC }_{i} \\
A P_{i} \\
\text { CACM }_{i} \\
\text { CARICOM }_{i} \\
E A_{i} \\
E_{i} \\
\text { EU }_{i} \\
\text { LAIA }_{i} \\
\text { MERCOSUR }_{i} \\
\text { NAFTA }_{i}\end{array}$ & $\begin{array}{l}1 \\
2 \\
1\end{array}$ & $\begin{array}{l}1 \\
1 \\
2 \\
2 \\
2\end{array}$ & $\begin{array}{l}1 \\
2 \\
2\end{array}$ \\
\hline Core gravity & $\begin{array}{l}\log \left(D I S T A N C E_{i j}\right) \\
\log \left(G D P_{i} G D P_{j}\right) \\
\log \left(g d p_{i} g d p_{j}\right)\end{array}$ & $\begin{array}{r}23 \\
9\end{array}$ & $\begin{array}{l}1 \\
2 \\
1\end{array}$ & $\begin{array}{r}23 \\
1 \\
2\end{array}$ \\
\hline Economic policy variables & $\begin{array}{l}S A C H S_{i}+S A C H S_{j} \\
C U_{i j} \\
F L O A T_{i j} \\
\text { VOLATILITY }_{i j}\end{array}$ & $\begin{array}{l}1 \\
3 \\
1 \\
1\end{array}$ & $\begin{array}{l}1 \\
1\end{array}$ & $\begin{array}{l}1 \\
4\end{array}$ \\
\hline Dev't/factor endowment & $\begin{array}{l}\operatorname{abs}\left(g d p \_D I F F\right) \\
\operatorname{abs}\left(D E N S \_D I F F\right) \\
\operatorname{abs}(S C H O O L \perp D I F F)\end{array}$ & $\begin{array}{l}3 \\
1\end{array}$ & $\begin{array}{l}1 \\
1 \\
1\end{array}$ & 1 \\
\hline Geography & $\begin{array}{l}\text { BORDER }_{i j} \\
\text { REMOTE }_{i j} \\
\text { LANDLOCK }_{i j} \\
\log \left(A R E A_{i} \text { AREA }_{j}\right) \\
\text { ISLAND }_{i j}\end{array}$ & $\begin{array}{r}19 \\
4 \\
3 \\
4 \\
3\end{array}$ & $\begin{array}{l}5 \\
3 \\
2 \\
1\end{array}$ & $\begin{array}{l}2 \\
1\end{array}$ \\
\hline Historical ties & $\begin{array}{l}\text { COMLANG }_{i j} \\
\text { COMCOL }_{i j} \\
\text { COLONY }_{i j}\end{array}$ & $\begin{array}{r}12 \\
3 \\
5\end{array}$ & 1 & $\begin{array}{l}1 \\
2\end{array}$ \\
\hline
\end{tabular}

Note: Following Ghosh and Yamarik (2004), from whom parts of this table are adapted, an estimated relationship is reported positive or negative when a paper reports the coefficient significant at the $1 \%$ level. One paper may have multiple entries for the same regressor, if different regressions in the paper yield different relationships. See Tables II(a)-(c) for additional variable description.

Sources: Aitken (1973); Aitken and Lowry (1973); Baier and Bergstrand (2007); Baldwin and Taglioni (2006); Baxter and Kouparitsas (2006); Bergstrand (1985); Brada and Mendez (1988); Carrere (2006); Cheng (2005); Coe and Hoffmaister (1999); Eichengreen and Irwin (1996); Egger (2000); Egger and Pfaffermayr (2003); Feenstra et al. (2001); Frankel (1992); Frankel and Rose (1998); Frankel et al. (1995); Frankel and Wei (1993, 1996); Freund (2000); Montenegro and Soto (1996); Rose (2000); Soloaga and Winters (2001); Thursby and Thursby (1987); Wei (1996); Wei and Frankel (1998); Wei and Zhang (2006). 
Economic policy variables that are commonly included relate to trade/financial openness and exchange rate management. These are important controls as trade restrictions can explain deviations from trade patterns implied by the pure gravity equation. The Sachs and Warner (1995) Trade Openness variable is inserted into the gravity equation to account for trade policy effects. In addition, proxies that measure capital account openness, and financial transaction costs such as Currency Union, Floating FX Rate, and FX Volatility are usually included, although it is not clear what coefficient estimates are to be expected. Clark et al. (2004) survey the literature and highlight that just this subset of regressors alone is so deeply affected by model uncertainty that the impact of exchange rate fluctuations depends on the specific assumptions of each model. ${ }^{19}$

Finally we address model uncertainty in the PTA theory itself. ${ }^{20}$ Not only do we have opposing implications suggested by different theories, but at times opposing theories have been suggested by the same author (see, for example, Krugman, 1991a,b). The theory of PTAs is based on Viner's (1950) theory of trade creation and diversion. By the 1990s, a full-scale discussion erupted regarding the drivers of trade creation and diversion. Krugman (1991a,b) examined the relative merits of PTAs in a static, monopolistically competitive framework that emphasized economic geography. His first model implied PTAs should not be welfare creating in the absence of intercontinental transport costs. At the other extreme, Krugman's second model suggested regional PTAs increase trade flows and subsequently welfare in the presence of prohibitive intercontinental transport costs.

Krugman's theories led Frankel et al. (1995), Frankel (1997), and Wei and Frankel (1998) to develop theories based on a continuum of transport costs. Their work characterizes trade partners as 'natural' on the basis of relatively low intercontinental transport costs and their approach implies that trade creation among 'natural' trading partners should dominate small trade diversion among remote country pairs from a welfare perspective. As trade costs fall, however, trade diversion may become larger since 'natural' trading partners overly skew their trade toward PTA partners. Frankel et al. (1995) suggest two hypotheses. First, the more remote trading partners are from the rest of the world, the more likely they are to form PTAs due to less potential trade diversion. This effect could be picked up by the Remoteness proxy. Second, the more 'natural' trading partners are, the more likely PTAs are to lead to trade creation.

Krugman's and Frankel et al.'s theories are based on one factor/one industry models. Deardorff and Stern (1994) note that these models preclude trade due to comparative advantage. Deardorff and Stern point out that this 'stacks the deck' against bilateralism and argue that, given differences in factor endowments, trade with a few countries suffices in order to maximize gains from trade. Thus trade diversion would be minimal. In response, Baier and Bergstrand (2004a) construct a model that builds upon Frankel et al. (1995) to allow for comparative advantage and scale effects. Freund (2000) argues strongly for PTA open bloc trade creation effects (even if trade creation among members is absent) since PTAs help outside exporters overcome fixed trade costs. Tradediverting effects, instead, are highlighted by Bond and Syropoulos (1996), who indicate that the increased market power of PTAs, relative to the market power of each member taken individually, may lead to higher external tariffs.

\subsection{Bayesian Model Averaging}

This section briefly outlines the BMA methodology used in the estimation. We limit ourselves to discussing the properties relevant to our application. The interested reader is referred to the

\footnotetext{
${ }^{19}$ Authors who introduced such regressors into the gravity equation include Rose (2000), Frankel and Rose (2002), Rose and van Wincoop (2001), Glick and Rose (2002), and Tenreyro and Barro (2007).

${ }^{20}$ For a more detailed literature review, see Panagariya $(1999,2000)$. 
comprehensive tutorial by Raftery et al. (1997) for further discussion. ${ }^{21}$ BMA is a natural candidate to address model uncertainty surrounding the correct controls in equations (1)-(4), since it provides probability distributions over both the model space and the parameter space. In our PTA estimation, the model space consists of all the possible subsets of candidate regressors that have been suggested by the distinct theories summarized above.

For linear regression models, the basic BMA setup can be concisely summarized as follows. Given a dependent variable, $Y$, a number of observations, $n$, and a set of candidate regressors, $X_{1}, X_{2}, \ldots, X_{k}$, the variable selection problem is to assess the quality of model:

$$
Y=\alpha+\sum_{j=1}^{p} \beta_{j} X_{j}+\varepsilon
$$

where $X_{1}, X_{2}, \ldots, X_{p}$ is a subset of $X_{1}, X_{2}, \ldots, X_{k}$, and $\beta$ is a vector of regression coefficients to be estimated. Note that (5) is specified for linear models. Given the data, $d$, BMA first estimates a posterior distribution $P\left(\beta_{r} \mid d, M_{k}\right)$, for every candidate regressor, $r$, in every model $M_{k}$ that includes $\beta_{r}$. It then combines all posterior distributions into a weighted averaged posterior distribution, $P\left(\beta_{r} \mid d\right)$, using each model's posterior probability, $P\left(M_{k} \mid d\right)$, as model weight:

$$
P\left(\beta_{r} \mid d\right)=\sum_{r \in M_{k}} P\left(\beta_{r} \mid d, M_{k}\right) P\left(M_{k} \mid d\right)
$$

The posterior model probability of $M_{k}$ is simply the ratio of its marginal likelihood to the sum of the marginal likelihoods over all other models:

$$
P\left(M_{k} \mid d\right)=\frac{l\left(d \mid M_{k}\right)}{\sum_{h=1}^{2^{k}} l\left(d \mid M_{h}\right)}
$$

where posterior model probabilities are also the weights used to establish the posterior means and variances:

$$
\begin{aligned}
& \mu \equiv E\left[\beta_{k} \mid d\right]=\sum_{k \in M}^{K} \hat{\beta}_{k} P\left(M_{k} \mid d\right) \\
& \sigma \equiv \operatorname{Var}\left[\beta_{k} \mid d\right]=\sum_{k \in M}^{K}\left(\operatorname{Var}\left[\beta_{k} \mid d, M_{k}\right]+\hat{\beta}_{k}^{2}\right) P\left(M_{k} \mid d\right)-E\left[\beta_{k} \mid d\right]^{2}
\end{aligned}
$$

Summing the posterior model probabilities over all models that include a candidate regressor, we obtain the posterior inclusion probability:

$$
P\left(\beta_{k} \neq 0 \mid d\right)=\sum_{r \in M} P\left(M_{k} \mid d\right)
$$

The posterior inclusion probability provides a probability statement regarding the importance of a regressor that directly addresses the researchers' prime concern: what is the probability that

\footnotetext{
${ }^{21}$ For recent methodological contributions to BMA see, for example, Doppelhofer and Weeks (2009), Ley and Steel (2009), and Eicher et al. (2010).
} 
the regressor has a non-zero relationship with the dependent variable? The general rule developed by Jeffries (1961) and refined by Kass and Raftery (1995) stipulates effect thresholds for posterior probability. Posterior probabilities $<50 \%$ are seen as evidence against an effect, while the evidence for an effect is either weak, positive, strong, or decisive for posterior probabilities of $50-75 \%, 75-95 \%, 95-99 \%$, and $>99 \%$, respectively. In our analysis, we refer to a regressor as 'effective' if its posterior inclusion probability exceeds $50 \%$.

BMA has a number of key advantages over estimating a single model, and over extreme bound analysis. Raftery and Zheng (2003) show that BMA (a) minimizes the total error rate (sum of Type I and Type II error probabilities), (b) its point estimates and predictions minimize mean squared error (MSE), and (c) its predictive distributions have optimal predictive performance relative to other approaches. Contrary to extreme bound analysis, BMA examines the entire model space and imposes no restrictions on the model size. Ghosh and Yamarik (2004) only consider models that contain a specific number of fixed variables. In addition to these fixed regressors, a fixed number of regressors is rotated in and out of ech regression. This approach limits the model search to a fraction of the model space that is spanned by all candidate regressors. This has been shown to render extreme bound analysis excessively stringent (see Sala-i-Martin, 1997).

\section{DATA}

Our dataset is based on the Ghosh and Yamarik (2004) dataset to allow for a direct re-examination of their evidence using BMA as our alternative statistical methodology. The Ghosh and Yamarik dataset is based on Frankel and Rose (2002) and it includes 12 PTAs, ${ }^{22} 3420$ bilateral trade pairs at 5-year intervals from 1970 to 1995 , and a total of 14,522 observations. ${ }^{23}$ This dataset features average bilateral trade as the dependent variable, recorded in US dollars and deflated by the US GDP chained price index. In addition to the basic gravity and trade agreement variables, 16 control variables have been suggested by various gravity approaches discussed above.

To address refinements in the theoretical and empirical trade flow specifications suggested by the recent literature, we expand the baseline dataset in several dimensions. We extend the time horizon from 1960 to 2000 and allow for 60 additional (bilateral) trade agreements that are included in the Subramanian and Wei (2007) dataset, which features 164 importers and 177 exporters. This increases the total number of observations to $37,983 .{ }^{24}$ We follow Subramanian and Wei (2007) and choose bilateral imports as the dependent variable; nominal imports are obtained from the IMF's Direction of Trade Statistics. ${ }^{25}$ Overall our updated dataset extends the unbalanced panel of Subramanian and Wei (2007) in the following three dimensions: (a) it disaggregates the Subramanian-Wei catch-all PTA variable; (b) it allows for additional PTAs not considered in

\footnotetext{
22 The PTAs are the European Union (EU), European Free Trade Arrangement (EFTA), European Economic Area (EEA), Central American Common Market (CACM), Caribbean Community (CARICOM), North American Free Trade Agreement (NAFTA), Latin American Integration Association (LAIA), Andean Pact (AP), Southern Cone Common Market (MERCOSUR), Association of South-East Asian Nations Free Trade Area (AFTA), Australia-New Zealand Trade Agreement (ANZCERTA), and Asian Pacific Economic Cooperation (APEC).

${ }^{23}$ See Ghosh and Yamarik (2004, Appendix C) for further details.

${ }^{24}$ With 177 countries in the IMF's Direction of Trade Statistics, as obtained by Subramanian and Wei (2007), potentially trading in the nine time periods from 1960 to 2000 , we have $177 \times 176 \times 9=280,368$ potential observations. Of these, 72,211 report non-zero values. Dropping observations with import values of less than $\$ 500,000$ reduces the dataset to 52,340 . Missing values for key covariates reduce the dataset by another 14,357 observations to yield our final dataset of 37,983 observations.

${ }^{25}$ Note that Subramanian and Wei (2007) deflate bilateral imports by the US CPI. Here we use nominal import values as they yield the same results once time fixed effects are included (see Baldwin and Taglioni, 2006).
} 
Table II(A). Preferential trading arrangements

\begin{tabular}{|c|c|c|c|}
\hline Abbreviation & Name of PTA & Start & Member countries \\
\hline ANZCERTA & $\begin{array}{l}\text { Australia-New Zealand Closer Economic } \\
\text { Relations Trade Agreement }\end{array}$ & 1983 & Australia, New Zealand \\
\hline APEC & Asia Pacific Economic Community & 1989 & $\begin{array}{l}\text { Australia, Brunei, Canada, China (1991), Chile } \\
\text { (1994), Taiwan (1991), Hong Kong (1991), } \\
\text { Indonesia, Japan, South Korea, Malaysia, } \\
\text { Mexico (1993), New Zealand, Papua New } \\
\text { Guinea (1993), Peru (1998), Philippines, } \\
\text { Singapore, Thailand, United States, Vietnam } \\
\text { (1998) }\end{array}$ \\
\hline AP & Andean Community/Andean Pact & 1969 & $\begin{array}{l}\text { Bolivia, Colombia, Ecuador, Peru, Venezuela } \\
\text { (1973). Former: Chile (1969-76) }\end{array}$ \\
\hline AFTA & $\begin{array}{l}\text { Association of South East Asian Nations } \\
\text { (ASEAN) Free Trade Area }\end{array}$ & 1967 & $\begin{array}{l}\text { Brunei (1984), Cambodia (1998), Indonesia, Laos } \\
\text { (1997), Malaysia, Myanmar (1997), } \\
\text { Philippines, Singapore, Thailand, Vietnam } \\
\text { (1995) }\end{array}$ \\
\hline CACM & Central American Common Market & 1960 & $\begin{array}{l}\text { Costa Rica (1963), El Salvador, Guatemala, } \\
\text { Honduras, Nicaragua }\end{array}$ \\
\hline CARICOM & Caribbean Community/Carifta & 1968 & $\begin{array}{l}\text { Antigua and Barbuda, Bahamas (1983), } \\
\text { Barbados, Belize (1995), Dominica (1974), } \\
\text { Guyana (1995), Grenada (1974), Jamaica, } \\
\text { Montserrat (1974), St Kitts and Nevis, St } \\
\text { Lucia (1974), St Vincent and the Grenadines, } \\
\text { Suriname (1995), Trinidad and Tobago }\end{array}$ \\
\hline EEA & European Economic Area & 1994 & $\begin{array}{l}\text { Austria, Belgium, Denmark, Finland, France, } \\
\text { Germany, Greece, Luxembourg, Iceland, Italy, } \\
\text { Ireland, Liechtenstein, Netherlands, Norway, } \\
\text { Portugal, Spain, Sweden, UK }\end{array}$ \\
\hline EFTA & European Free Trade Association & 1960 & $\begin{array}{l}\text { Iceland, Liechtenstein (1991), Norway (1986), } \\
\text { Switzerland. Former: Denmark (1960-72), UK } \\
\text { (1960-72), Portugal (1960-85), Austria } \\
\text { (1960-94), Sweden (1960-94), Finland } \\
\text { (1986-94) }\end{array}$ \\
\hline EU & European Union & 1958 & $\begin{array}{l}\text { Austria (1995), Belgium, Denmark (1973), } \\
\text { Finland (1995), France, Germany, Greece } \\
\text { (1981), Luxembourg, Ireland (1973), Italy, } \\
\text { Netherlands, Portugal (1986), Spain (1986), } \\
\text { Sweden (1995), UK (1973) }\end{array}$ \\
\hline LAIA/LAFTA & Latin America Integration Agreement & 1960 & $\begin{array}{l}\text { Argentina, Bolivia (1967), Brazil, Chile, } \\
\text { Colombia (1961) Ecuador (1961), Mexico, } \\
\text { Paraguay, Peru, Uruguay, Venezuela (1966) }\end{array}$ \\
\hline MERCOSUR & Southern Cone Common Market & 1991 & Argentina, Brazil, Paraguay, Uruguay \\
\hline NAFTA & $\begin{array}{l}\text { Canada-US Free Trade Arrangement/North } \\
\text { America Free Trade Agreement }\end{array}$ & 1988 & Canada, USA, Mexico (1994) \\
\hline BilateralPTA & Bilateral Preferential Trade Agreements & & $\begin{array}{l}\text { All bilateral agreements considered are listed in } \\
\text { Table II(b) }\end{array}$ \\
\hline
\end{tabular}

Note: This table is based on Ghosh and Yamarik (2004) and includes corrections to some of the original PTA coding as follows. ASEAN, which is no free trade area, was changed to AFTA, with AFTA membership starting in 1992 instead of 1980. For the Andean Pact, Chile had to be excluded post 1976, when it left the AP. Finally, CARICOM membership for Guyana is corrected to start in 1973 (instead of 1995). The corrections do not alter the qualitative results.

Subramanian and Wei (2007), ${ }^{26}$ and (c) it incorporates a comprehensive list of additional controls suggested by the previous literature. Detailed descriptions of the PTAs and the other control variables included in the extended dataset can be found in Tables II(a)-(c).

\footnotetext{
${ }^{26}$ This extension adds the European Free Trade Agreement (EFTA), the European Economic Area (EEA), the Andean Pact (AP), the Latin American Integration Association and the Asia Pacific Economic Community (APEC) to the analysis. 
Table II(B). Bilateral Preferential Trade Agreements considered in BilateralPTA

\begin{tabular}{|c|c|}
\hline $\begin{array}{l}\text { USA-Israel } \\
\text { Turkey-Slovenia }\end{array}$ & $\begin{array}{l}\text { Slovak Republic-Turkey } \\
\text { Papua New Guinea-Australia Trade \& Commercial } \\
\text { Relations Agreement (PATCRA) }\end{array}$ \\
\hline EC-Slovenia & EC-Tunisia \\
\hline EC-Lithuania & Estonia-Turkey \\
\hline EC-Estonia & Slovenia-Israel \\
\hline EC-Latvia & Poland-Israel \\
\hline Chile-Mexico & Estonia-Faroe Islands \\
\hline Mexico-Israel & Czech Republic-Estonia \\
\hline Georgia-Armenia & Slovak Republic-Estonia \\
\hline Georgia-Azerbaijan & Lithuania-Turkey \\
\hline Georgia-Kazakhstan & Israel-Turkey \\
\hline Georgia-Turkmenistan & Romania-Turkey \\
\hline Georgia-Ukraine & Hungary-Turkey \\
\hline Latvia-Turkey & Czech Republic-Israel \\
\hline Turkey-former Yugoslav Rep. of Macedonia & Slovak Republic-Israel \\
\hline EC-South Africa & Slovenia-Croatia \\
\hline EC-Morocco & Hungary-Israel \\
\hline EC-Israel & CEFTA accession of Romania \\
\hline EC-Mexico & CEFTA accession of Slovenia \\
\hline Estonia-Ukraine & Poland-Lithuania \\
\hline Poland-Turkey & Slovak Republic-Latvia \\
\hline EFTA-Morocco & Slovak Republic-Lithuania \\
\hline Bulgaria-former Yugoslav Rep. of Macedonia & Canada-Chile \\
\hline Hungary-Latvia & Czech Republic-Latvia \\
\hline Hungary-Lithuania & Czech Republic-Lithuania \\
\hline Poland-Latvia & Slovenia-Estonia \\
\hline Poland-Faeroe Islands & Slovenia-Lithuania \\
\hline Kyrgyz Republic-Moldova & EC-Faeroe Islands \\
\hline Kyrgyz Republic-Ukraine & Canada-Israel \\
\hline Kyrgyz Republic-Uzbekistan & EFTA-Estonia \\
\hline Bulgaria-Turkey & EFTA-Latvia \\
\hline Czech Republic-Turkey & EFTA-Lithuania \\
\hline EAEC & EC-Turkey \\
\hline CEFTA accession of Bulgaria & \\
\hline
\end{tabular}

Source: Subramanian and Wei (2007).

The Subramanian and Wei (2007) data are in turn based on Rose (2004) and Glick and Rose (2002) work on the determinants of trade flows; we maintain their convention of including only those of the roughly 280,000 observations whose trade values exceed $\$ 500,000$. There exists, however, an important literature that seeks to understand the true nature of the data when zero trade flows are observed. Zero trade values may also be due to a rounding error or missing observations, and in a log-linear gravity equation zeros are automatically excluded. If a zero trade value were to be an accurate representation of two countries' goods trade, the observation should not be excluded, since it holds information and its absence may induce selection bias.

Santos Silva and Tenreyro (2006) suggest the Poisson pseudo-maximum likelihood (PPML) estimator to appropriately address the issue of zero trade values. This method has been shown to reduce estimates by as much as $40 \%$. Martin and Pham (2008) suggest that the PPML estimator is efficient in addressing heterogeneity, but still biased in the presence of zero trade values. Based on the results of their simulations, they instead recommend a Heckman maximum likelihood approach to control for selection bias. Below we follow Rose's and Subramanian and Wei's OLS approach not only to maintain comparability with their results, but also because neither a PPML nor a Heckman estimator has been developed to date for BMA application. 
Table II(C). Description of non-PTA related variables

\begin{tabular}{|c|c|c|}
\hline Variable & Description & Source \\
\hline $\log \left(I M P O R T S_{i j t}\right)$ & $\begin{array}{l}\text { Natural log of bilateral imports (current } \\
\text { US dollars) }\end{array}$ & IMF Direction of Trade Statistics \\
\hline $\log \left(D I S T A N C E_{i j}\right)$ & Natural $\log$ of the bilateral distance & Subramanian and Wei (2007) \\
\hline $\log \left(G D P_{i t} G D P_{j t}\right)$ & $\begin{array}{l}\text { Natural log of the product of nominal } \\
\text { GDP }\end{array}$ & Penn World Tables \\
\hline $\log \left(g d p_{i t} g d p_{j t}\right)$ & $\begin{array}{l}\text { Natural log of the product of real GDP } \\
\text { per capita }\end{array}$ & Penn World Tables \\
\hline$S A C H S_{i t}+S A C H S_{j t}$ & $\begin{array}{l}\text { The sum of the Sachs-Warner index of an } \\
\text { open trade policy }\end{array}$ & $\begin{array}{l}\text { Sachs and Warner (1995); } \\
\text { Wacziarg and Welch (2003) }\end{array}$ \\
\hline$C U_{i j t}$ & $\begin{array}{l}\text { Dummy ( } 1 \text { if the two share a common } \\
\text { currency) }\end{array}$ & Subramanian and Wei (2007) \\
\hline$F L O A T_{i j t}$ & $\begin{array}{l}\text { Number of countries with a floating } \\
\text { exchange rate }(0,1,2)\end{array}$ & $\begin{array}{l}\text { IMF Annual Report on Exchange } \\
\text { Rate Arrangements and } \\
\text { Restrictions }\end{array}$ \\
\hline VOLATILITY $_{i j t}$ & $\begin{array}{l}\text { Standard deviation of the first difference } \\
\text { in the bilateral exchange rate during the } \\
\text { previous } 3 \text { years }\end{array}$ & $\begin{array}{l}\text { IMF International Financial } \\
\text { Statistics }\end{array}$ \\
\hline $\operatorname{abs}(g d p \perp I F F)$ & $\begin{array}{l}\text { Absolute log difference of real GDP per } \\
\text { capita }\end{array}$ & Penn World Tables \\
\hline $\operatorname{abs}\left(D E N S \_D I F F\right)$ & $\begin{array}{l}\text { Absolute log difference in population } \\
\text { density }\end{array}$ & CIA World Fact Book \\
\hline $\operatorname{abs}\left(S C H O O L \_D I F F\right)$ & $\begin{array}{l}\text { Absolute log difference in the average } \\
\text { years of secondary schooling in the } \\
25+\text { population }\end{array}$ & Barro and Lee (2001) \\
\hline$B O R D E R_{i j}$ & $\begin{array}{l}\text { Dummy ( } 1 \text { if the two share a common } \\
\text { land border and } 0 \text { otherwise) }\end{array}$ & Subramanian and Wei (2007) \\
\hline$R_{E M O T E_{i j t}}$ & $\begin{array}{l}\text { Natural log of the product of the average } \\
\text { distance (weighted by relative GDP) of } \\
\text { each country from all trading partners }\end{array}$ & $\begin{array}{l}\text { CIA World Fact Book and Penn } \\
\text { World Tables }\end{array}$ \\
\hline$L A N D L O C K_{i j}$ & Number of landlocked countries $(0,1,2)$ & Subramanian and Wei (2007) \\
\hline $\log \left(A R E A_{i} A R E A_{j}\right)$ & $\begin{array}{l}\text { Natural log of the product of the surface } \\
\text { area of the two countries }\end{array}$ & CIA World Fact Book \\
\hline$I_{S L A N D_{i j}}$ & Number of island countries $(0,1,2)$ & Subramanian and Wei (2007) \\
\hline$C O M L A N G_{i j}$ & $\begin{array}{l}\text { Dummy ( } 1 \text { if the two share a common } \\
\text { language and } 0 \text { otherwise) }\end{array}$ & Subramanian and Wei (2007) \\
\hline $\mathrm{COMCOL}_{i j}$ & $\begin{array}{l}\text { Dummy ( } 1 \text { if the two share a common } \\
\text { colonizer and } 0 \text { otherwise) }\end{array}$ & Subramanian and Wei (2007) \\
\hline $\mathrm{COLONY}_{i j}$ & $\begin{array}{l}\text { Dummy ( } 1 \text { if one was a former colony of } \\
\text { the other and } 0 \text { otherwise) }\end{array}$ & Subramanian and Wei (2007) \\
\hline
\end{tabular}

a The remoteness variable is constructed as in Rose (2000). The use of the Ghosh and Yamarik (2004) remoteness variable does not alter the qualitative results.

\section{RESULTS}

\subsection{PTA Trade Creation: Differences Due to Methodologies}

Ghosh and Yamarik (2004) embarked on the most comprehensive robustness test of PTAs to date. They considered not just a subset but all major PTAs and employed extreme bound analysis to explore the model space far beyond what ordinary robustness exercises can hope to represent. Our first objective is to replicate Ghosh and Yamarik's (2004) results using BMA methodology. Table III reports results for two specifications. Specification 1 employs BMA on the exact same data and regression equation in Ghosh and Yamarik (2004, equation 1). Specification 2 differs from Specification 1 only in that it uses our new updated dataset based on Subramanian and Wei (2007).

Table III highlights that our key result is independent of the choice of PTA dataset that is used. Once model uncertainty is addressed in a principled fashion using BMA, Ghosh and Yamarik's 
Table III. PTA trade creation and trade diversion

\begin{tabular}{|c|c|c|c|c|c|c|c|}
\hline & & \multicolumn{3}{|c|}{$\begin{array}{l}\text { Specification } 1 \\
\text { Time fixed effects } \\
\text { Original Ghosh and } \\
\text { Yamarik (2004) } \\
\text { specification and data }\end{array}$} & \multicolumn{3}{|c|}{$\begin{array}{c}\text { Specification } 2 \\
\text { Time fixed effects } \\
\text { Ghosh and Yamarik } \\
\text { (2004) specification, } \\
\text { updated Subramanian/Wei data }\end{array}$} \\
\hline & & $p \neq 0$ & $\mu$ & $\sigma$ & $p \neq 0$ & $\mu$ & $\sigma$ \\
\hline Trade creation & $\begin{array}{l}\text { AFTA }_{i j t} \\
\text { ANZCERTA }_{i j t} \\
\text { APEC } \\
\text { AP } \\
\text { CA }_{i j t} \\
\text { CACM }_{i j t} \\
\text { EARICOM }_{i j t} \\
\text { EEA }_{i j t} \\
\text { EU }_{i j t} \\
\text { LAIA }_{i j t} \\
\text { MERCOSUR }_{i j t} \\
\text { NAFTA }_{i j t} \\
\text { BILATERAL }_{i j t}\end{array}$ & $\begin{array}{r}0 \\
1 \\
100 \\
1 \\
100 \\
100 \\
1 \\
0 \\
0 \\
91 \\
12 \\
1 \\
\text { n.a }\end{array}$ & $\begin{array}{l}-0.22 \\
0.89 \\
1.48^{* * *} \\
-0.05 \\
2.25^{* * *} \\
2.08^{* * *} \\
0.26 \\
0.02 \\
0.03 \\
0.46^{* * *} \\
1.66 \\
-0.89 \\
\text { n.a }\end{array}$ & $\begin{array}{l}0.54 \\
0.96 \\
0.15 \\
0.27 \\
0.23 \\
0.41 \\
0.19 \\
0.26 \\
0.14 \\
0.13 \\
0.7 \\
0.84 \\
\text { n.a }\end{array}$ & $\begin{array}{r}1 \\
1 \\
100 \\
99 \\
100 \\
100 \\
2 \\
100 \\
100 \\
1 \\
14 \\
0 \\
1\end{array}$ & $\begin{array}{l}0.36 \\
0.88 \\
1.71^{* * *} \\
0.67^{* * *} \\
2.30^{* * *} \\
2.83^{* * *} \\
0.22 \\
0.67^{* * *} \\
0.51^{* * *} \\
-0.05 \\
0.96 \\
0.20 \\
0.13\end{array}$ & $\begin{array}{l}0.35 \\
0.62 \\
0.09 \\
0.15 \\
0.15 \\
0.30 \\
0.15 \\
0.13 \\
0.09 \\
0.08 \\
0.36 \\
0.47 \\
0.13\end{array}$ \\
\hline $\begin{array}{l}\text { Trade diversion, } \\
\text { open bloc }\end{array}$ & $\begin{array}{l}\text { AFTA }_{i t} \\
\text { ANZCERTA }_{i t} \\
\text { APEC }_{i t} \\
A P_{i t} \\
\text { CACM }_{i t} \\
\text { CARICOM }_{i t} \\
E E A_{i t} \\
\text { EFTA }_{i t} \\
\text { EU it }_{i t} \\
\text { LAIA }_{i t} \\
\text { MERCOSUR }_{i t} \\
\text { NAFTA }_{i t} \\
\text { BILATERAL }_{i t}\end{array}$ & $\begin{array}{r}3 \\
\\
100 \\
100 \\
52 \\
85 \\
100 \\
0 \\
100 \\
100 \\
100 \\
79 \\
100 \\
\text { n.a }\end{array}$ & $\begin{array}{c}0.17 \\
-0.47^{* * *} \\
0.55^{* * *} \\
-0.19^{*} \\
-0.18^{* *} \\
-0.74^{* * *} \\
0.01 \\
0.35^{* * *} \\
0.56^{* * *} \\
-0.40^{* * *} \\
0.42^{* *} \\
-0.63^{* * *} \\
\text { n.a }\end{array}$ & $\begin{array}{l}0.11 \\
0.1 \\
0.06 \\
0.06 \\
0.05 \\
0.07 \\
0.08 \\
0.05 \\
0.04 \\
0.07 \\
0.12 \\
0.1 \\
\text { n.a }\end{array}$ & $\begin{array}{r}100 \\
100 \\
100 \\
2 \\
100 \\
100 \\
92 \\
100 \\
100 \\
100 \\
0 \\
4 \\
100\end{array}$ & $\begin{array}{c}0.41^{* * *} \\
-0.81^{* * *} \\
0.48^{* * *} \\
0.07 \\
-0.17^{* * *} \\
-0.58^{* * *} \\
-0.17^{* *} \\
0.37^{* * *} \\
0.65^{* * *} \\
-0.52^{* * *} \\
-0.04 \\
0.13 \\
-0.27^{* * *}\end{array}$ & $\begin{array}{l}0.06 \\
\\
0.06 \\
0.04 \\
0.04 \\
0.03 \\
0.05 \\
0.04 \\
0.03 \\
0.03 \\
0.03 \\
0.06 \\
0.06 \\
0.04\end{array}$ \\
\hline Core gravity & $\begin{array}{l}\log \left(G D P_{i t} G D P_{j t}\right) \\
\log \left(D I S T A N C E_{i j}\right) \\
\log \left(g d p_{i t} g d p_{j t}\right)\end{array}$ & $\begin{array}{l}100 \\
100 \\
100\end{array}$ & $\begin{array}{r}0.88^{* * *} \\
-1.19^{* * *} \\
0.55^{* * *}\end{array}$ & $\begin{array}{l}0.01 \\
0.02 \\
0.02\end{array}$ & $\begin{array}{l}100 \\
100 \\
100\end{array}$ & $\begin{array}{r}0.94^{* * *} \\
-1.08^{* * *} \\
0.28^{* * *}\end{array}$ & $\begin{array}{l}0.01 \\
0.02 \\
0.01\end{array}$ \\
\hline Economic policy & $\begin{array}{l}\text {SSACHS }_{i t}+S A C H S_{j t} \\
\text { VOLATILITY }_{i j t} \\
\text { FLOAT }_{i j t} \\
C U_{i j t}\end{array}$ & $\begin{array}{r}100 \\
25 \\
0 \\
100\end{array}$ & $\begin{array}{l}0.35^{* * *} \\
0.006 \\
-0.01 \\
1.40^{* * *}\end{array}$ & $\begin{array}{l}0.03 \\
0.002 \\
0.02 \\
0.29\end{array}$ & $\begin{array}{r}100 \\
0 \\
100 \\
100\end{array}$ & $\begin{array}{c}0.22^{* * *} \\
-0.0003 \\
0.09^{* * *} \\
1.22^{* * *}\end{array}$ & $\begin{array}{l}0.02 \\
0.00 \\
0.02 \\
0.10\end{array}$ \\
\hline $\begin{array}{l}\text { Development, factor } \\
\text { endowments }\end{array}$ & $\begin{array}{l}\operatorname{abs}\left(S C H O O L \_D I F F\right) \\
\operatorname{abs}\left(D E N S \_D I F F\right) \\
\operatorname{abs}\left(g d p \_D I F F\right)\end{array}$ & $\begin{array}{r}1 \\
100 \\
100\end{array}$ & $\begin{array}{l}0.02 \\
0.23^{* * *} \\
0.18^{* * *}\end{array}$ & $\begin{array}{l}0.02 \\
0.01 \\
0.02\end{array}$ & $\begin{array}{l}14 \\
100 \\
100\end{array}$ & $\begin{array}{l}0.04 \\
0.13^{* * *} \\
0.08^{* * *}\end{array}$ & $\begin{array}{l}0.02 \\
0.01 \\
0.01\end{array}$ \\
\hline Geography & $\begin{array}{l}\text { BORDER }_{i j} \\
\operatorname{ISLAND}_{i j} \\
\text { LANDLOCK }_{i j} \\
\log \left(\text { AREA }_{i} \text { AREA }_{j}\right) \\
\text { REMOTE }_{i j t}\end{array}$ & $\begin{array}{r}100 \\
2 \\
100 \\
92 \\
100\end{array}$ & $\begin{aligned} & 0.53^{* * *} \\
- & 0.05 \\
- & 0.42^{* * *} \\
- & 0.03^{* *} \\
& 342^{* * *}\end{aligned}$ & $\begin{array}{r}0.1 \\
0.03 \\
0.04 \\
0.01 \\
39.79\end{array}$ & $\begin{array}{l}100 \\
100 \\
100 \\
100 \\
100\end{array}$ & $\begin{array}{r}0.40^{* * *} \\
-0.22^{* * *} \\
-0.26^{* * *} \\
-0.08^{* * *} \\
1.31^{* * *}\end{array}$ & $\begin{array}{l}0.06 \\
0.03 \\
0.02 \\
0.01 \\
0.04\end{array}$ \\
\hline History & $\begin{array}{l}\operatorname{COLONY}_{i j} \\
\text { COMCOL }_{i j} \\
\text { COMLANG }_{i j}\end{array}$ & $\begin{array}{l}100 \\
100 \\
100\end{array}$ & $\begin{array}{l}1.44^{* * *} \\
0.77^{* * *} \\
0.47^{* * *}\end{array}$ & $\begin{array}{l}0.12 \\
0.07 \\
0.05\end{array}$ & $\begin{array}{l}100 \\
100 \\
100\end{array}$ & $\begin{array}{l}1.12^{* * *} \\
0.55^{* * *} \\
0.28^{* * *}\end{array}$ & $\begin{array}{l}0.06 \\
0.04 \\
0.02\end{array}$ \\
\hline
\end{tabular}

Note: Fixed effect coefficients are omitted. Asterisks represent weak, positive, and decisive evidence for an effect of the regressor, corresponding to posterior inclusion probabilities of $* 50-75 \%,{ }^{* *} 75-99 \%$, and $* * *>99 \%$, respectively (see Jefferies, 1961; Kass and Raftery, 1995). $p \neq 0$ is the inclusion probability, $\mu$ is the posterior mean, and $\sigma$ is the posterior standard deviation. 
(2004) own econometric specification produces a host of PTA effects that range from trade creating to open bloc and even trade diverting. We obtain effective coefficients (indicated with asterisks) whose signs and magnitudes are similar to those commonly reported in the previous literature. BMA thus provides evidence that the model space spanned by 'free and doubtful variables' through extreme bound analysis was too restrictive. The models flagged out by extreme bound analysis did not contain those that feature the highest posterior probabilities, and the heuristic model weighting assigned by extreme bound analysis generated excessively conservative results that indicated no PTA effects. The expanded model space, combined with the principled weighting of effective models, generate BMA's superior predictive performance.

Of the 13 major trade agreements, eight are found to be either trade creating and/or to exhibit open bloc effects in Specification 1. All Western Hemisphere PTAs are identified as trade diverting in the original Ghosh and Yamarik dataset (Specification 1). The additional years and controls for bilateral agreements in our updated dataset (Specification 2) increase the precision of the estimates, but our key insights remain the same. Specification 2 produces four additional trade creation effects (for key PTAs such as the EFTA, AFTA and the EU), and erases the odd implication of NAFTA trade diversion that was reported by Specification 1. These changes are most certainly due to the extension of the time horizon from the mid 1990s to 2000. In summary, the BMA results robustly link PTAs to changes in trade flows, although the effects vary across PTAs.

A substantial literature addresses the possibility of PTA coefficient bias due to omitted variables or inaccurate model specification. We extend our analysis to incorporate the insights of this recent literature to examine the robustness of our results. The scale of some PTA coefficients in Table III is certainly suspicious if not implausible. Coefficients that exceed unity imply that a PTA increased trade more than twofold (since the regression is in logs). Such aberrant magnitudes have previously been noted and questioned in the literature (e.g. Frankel, 1992, 1997; Frankel and Wei, 1993; Frankel et al., 1995). We take up the issue of omitted variable bias in the following section.

\subsection{Multilateral Resistance}

Ghosh and Yamarik (2004) and our Specifications 1 and 2 (Table III) include time fixed effects, but the recent PTA literature suggests the inclusion of additional fixed effects to account for multilateral trade costs. Wei (1996), Deardorff (1998), Anderson and van Wincoop (2003), and Subramanian and Wei (2007) emphasized that the standard gravity model is subject to misspecification bias if multilateral trade costs are ignored. The crucial insight is that bilateral trade is influenced by the average multilateral trade cost faced by a country in any given period. Anderson and van Wincoop (2003) suggest that, empirically, the inclusion of country fixed effects captures multilateral resistance. Since bilateral trade between any two countries depends on the multilateral resistance of both importers and exporters, the Anderson and van Wincoop (2003) model requires fixed effects for both countries involved in any bilateral trading relationship. ${ }^{27}$ In a panel, these importer and exporter fixed effects must be time varying, which allows the PTA dummies in equation (2) to identify net trade creation. This fixed-effect approach has been popularized by Subramanian and Wei (2007) in their analysis of WTO trade effects (although these authors do not break out the effects of individual PTAs).

Specification 4 reports results that control for multilateral resistance. Specification 3 replicates the results in Specification 2, without separate trade diversion/open bloc effects. As expected, the results for most trade agreements are very similar to the sum of trade creation and diversion in Specification 2. For example, the Central American Common Market (CACM) featured a

\footnotetext{
${ }^{27}$ Helpman et al. (2008) suggest an alternative rationale for importer and exporter fixed effects based on firm heterogeneity.
} 
coefficient for trade creation of 2.3 in Specification 2, and a trade diversion effect with the rest of the world of 0.17. The combined net trade creation for PTA members is then an implied 2.47, which is closely matched by the estimate of 2.45 in Specification 3.

More importantly, however, Table IV shows that even after controlling for multilateral resistance the fundamental result of our analysis remains unchanged: PTAs have a strong impact on bilateral trade. Of the 13 major PTAs covered, 10 PTAs exhibit an effect on bilateral trade, only one of which is negative. This implies that controlling for multilateral resistance identifies four additional PTAs with significant positive impacts on bilateral trade flows.

The one surprise in Specification 4 is the implied negative net trade creation for the EU. The attractiveness of the EU market with its large size and strong harmonization likely exerts a significant pull on non-EU exporters, resulting in the large open bloc effects estimated at about 0.6 in Specifications 1 and 2. The drag of open bloc effects on net trade creation by itself thus explains roughly half of the negative coefficient estimate. In addition, it is well known that the gravity equation overpredicts EU trade when estimated on a global sample. Given their close proximity and other bilateral characteristics, EU countries undertrade relative to the globally based prediction, resulting in a negative EU coefficient. This may be related to the gravity equation's inability to proxy firms' fixed costs in establishing trade relations (e.g. Freund, 2000). Empirically, Aitken (1973) and Rose (2004) find similarly negative EU results. Inclusion of country-pair fixed effects is commonly suggested to control for such time-invariant bilateral heterogeneity. It represents the main alternative to time-varying importer/exporter fixed effects for our robustness analysis. By examining EEA, EFTA and EU effects across alternative fixed-effects specifications, Baier et al. (2008) also find a similar instability and turn to country-pair fixed effects to obtain robust effects.

\subsection{Unobserved Heterogeneity}

To capture unobserved time-invariant heterogeneity among trade partners, we re-estimate Specification 4, accounting for country-pair fixed effects. This specification does not address multilateral trade costs as comprehensively as suggested by Anderson and van Wincoop (2003), especially if they exhibit large fluctuations over time. However, Rose (2004) makes the point that country-pair fixed effects constitute a valid proxy for average multilateral resistance exhibited in country pairs. Hummels and Levinsohn (1995) first introduced country-pair fixed effects to better distinguish between factor endowments and market structure as trade flow drivers. Egger and Pfaffermayr (2003) advocate country-pair fixed effects to account for heterogeneity induced by time-invariant factors (e.g., geography, history, policy, and culture) that are only partially accounted for by the explanatory variables or completely unobserved. Glick and Rose (2002) use the same specification as Egger and Pfaffermayr (2003), but motivate country-pair fixed effects as proxies for trade resistance. Here we employ it as a robustness test of the estimated parameter magnitudes for specific PTAs, such as the EU.

Note that the introduction of country-pair fixed effects removes the cross-sectional information so that Specification 5 relies only on the time series information contained in the data. Specification 5, therefore, expresses only PTA effects directly caused by PTA accession or exit. Nevertheless, our central result remains robust: PTAs exert a significant effect on trade flows. The rewarding aspect of the country-pair analysis is that BMA confirms the hypothesis that the gravity model overpredicts intra-European trade flows only when pair-specific heterogeneity is ignored. Once these effects are accounted for, EU trade creation is indeed positive. On the other hand, some effects that seemed unreasonably large before are now significantly reduced. ANZCERTA, AP, EEA and MERCOSUR lose their influence on net trade flows, which indicates considerable unobserved bilateral heterogeneity members of these PTAs. With the exception of the Latin 
Table IV. PTA net trade creation controlling for multilateral resistance and bilateral heterogeneity

\begin{tabular}{|c|c|c|c|c|c|c|c|c|c|c|c|c|}
\hline \multirow{7}{*}{$\begin{array}{l}\text { Subramanian/ } \\
\text { Wei data } \\
\text { Time fixed } \\
\text { effects } \\
\text { Imp. exp. fixed } \\
\text { effects } \\
\text { Country-pair } \\
\text { fixed effects } \\
\text { Accession } \\
\text { dynamics }\end{array}$} & \multicolumn{3}{|c|}{ Specification 3} & \multicolumn{3}{|c|}{ Specification 4} & \multicolumn{3}{|c|}{ Specification 5} & \multicolumn{3}{|c|}{ Specification 6} \\
\hline & \multicolumn{3}{|c|}{ Yes } & \multicolumn{3}{|c|}{ Yes } & \multicolumn{3}{|c|}{ Yes } & \multicolumn{3}{|c|}{ Yes } \\
\hline & \multicolumn{3}{|c|}{ Yes } & \multicolumn{3}{|c|}{ Yes } & \multicolumn{3}{|c|}{ Yes } & \multicolumn{3}{|c|}{ Yes } \\
\hline & \multicolumn{3}{|c|}{ No } & \multicolumn{3}{|c|}{ Yes } & \multicolumn{3}{|c|}{ No } & \multicolumn{3}{|c|}{ Yes } \\
\hline & \multicolumn{3}{|c|}{ No } & \multicolumn{3}{|c|}{ No } & \multicolumn{3}{|c|}{ Yes } & \multicolumn{3}{|c|}{ Yes } \\
\hline & \multicolumn{3}{|c|}{ No } & \multicolumn{3}{|c|}{ No } & \multicolumn{3}{|c|}{ No } & & No & \\
\hline & $p \neq 0$ & $\mu$ & $\sigma$ & $p \neq 0$ & $\mu$ & $\sigma$ & $p \neq 0$ & $\mu$ & $\sigma$ & $p \neq 0$ & $\mu$ & $\sigma$ \\
\hline$A F T A_{i j t}$ & 1 & 0.46 & 0.35 & 1 & -0.36 & 0.32 & 1 & 0.27 & 0.24 & 2 & -0.38 & 0.29 \\
\hline ANZCERTA $_{i j t}$ & 19 & 1.73 & 0.63 & 94 & $2.15^{* *}$ & 0.56 & 0 & -0.02 & 0.51 & 3 & 0.89 & 0.60 \\
\hline$A P E C_{i j t}$ & 100 & $1.39^{* * *}$ & 0.08 & 100 & $0.62^{* * *}$ & 0.09 & 100 & $0.52^{* * *}$ & 0.06 & 1 & 0.09 & 0.08 \\
\hline$A P_{i j t}$ & 88 & $0.63^{* *}$ & 0.16 & 93 & $0.59^{* *}$ & 0.15 & 6 & 0.44 & 0.19 & 99 & $0.80^{* *}$ & 0.24 \\
\hline$C A C M_{i j t}$ & 100 & $2.45^{* * *}$ & 0.15 & 100 & $2.34^{* * *}$ & 0.14 & 100 & $2.19^{* * *}$ & 0.26 & 100 & $1.59^{* * *}$ & 0.37 \\
\hline CARICOM $_{i j t}$ & 100 & $2.89^{* * *}$ & 0.31 & 100 & $4.27^{* * *}$ & 0.28 & 63 & $1.45^{*}$ & 0.43 & 92 & $1.59^{* *}$ & 0.53 \\
\hline$E E A_{i j t}$ & 10 & 0.35 & 0.13 & 99 & $0.49^{* *}$ & 0.12 & 25 & -0.24 & 0.08 & 100 & $0.49^{* * *}$ & 0.11 \\
\hline$E F T A_{i j t}$ & 1 & 0.15 & 0.12 & 2 & -0.17 & 0.11 & 5 & 0.26 & 0.12 & 1 & -0.08 & 0.15 \\
\hline$E U_{i j t}$ & 19 & -0.29 & 0.13 & 100 & $-1.18^{* * *}$ & 0.10 & 100 & $0.41^{* * *}$ & 0.10 & 21 & 0.25 & 0.12 \\
\hline$L A I A_{i j t}$ & 100 & $0.40^{* * *}$ & 0.09 & 100 & $0.93^{* * *}$ & 0.08 & 100 & $1.68^{* * *}$ & 0.19 & 100 & $1.18^{* * *}$ & 0.27 \\
\hline$M_{E R C O S U R} i j t$ & 6 & 0.79 & 0.37 & 80 & $1.19^{* *}$ & 0.34 & 1 & 0.38 & 0.26 & 1 & 0.35 & 0.31 \\
\hline$N_{A F T A} A_{i j t}$ & 1 & -0.25 & 0.48 & 0 & 0.09 & 0.43 & 1 & 0.48 & 0.34 & 2 & 0.53 & 0.40 \\
\hline BILATERAL $_{i j t}$ & 12 & 0.34 & 0.13 & 53 & $0.41^{*}$ & 0.13 & 14 & 0.24 & 0.09 & 0 & 0.01 & 0.12 \\
\hline $\log \left(G D P_{i t} G D P_{j t}\right)$ & 100 & $1.02^{* * *}$ & 0.01 & & & & 15 & 0.01 & 0.00 & & & \\
\hline $\log \left(D_{S T A N C E} E_{i j}\right)$ & 100 & $-1.09^{* * *}$ & 0.02 & 100 & $-1.18^{* * *}$ & 0.02 & & & & & & \\
\hline $\log \left(g d p_{i t} g d p_{j t}\right)$ & 100 & $0.18^{* * *}$ & 0.01 & & & & 100 & $1.06^{* * *}$ & 0.02 & & & \\
\hline$S A C H S_{i j t}$ & 100 & $0.34^{* * *}$ & 0.02 & & & & 100 & $0.20^{* * *}$ & 0.02 & & & \\
\hline VOLATILITY $_{i j t}$ & 1 & 0 & 0.00 & 1 & 0.00 & 0.01 & 100 & $-0.01^{* * *}$ & 0.00 & 1 & 0.00 & 0.01 \\
\hline$F L O A T_{i j t}$ & 3 & 0.03 & 0.02 & & & & 100 & $-0.06^{* * *}$ & 0.01 & & & \\
\hline$C U_{i j t}$ & 100 & $1.26^{* * *}$ & 0.10 & 100 & $1.15^{* * *}$ & 0.10 & 100 & $0.66^{* * *}$ & 0.13 & 6 & 0.28 & 0.16 \\
\hline $\mid$ SCHOOL_DIFF $\mid$ & 100 & $0.08^{* * *}$ & 0.01 & 23 & $0.05^{* *}$ & 0.02 & 100 & $0.23^{* * *}$ & 0.02 & 20 & 0.07 & 0.03 \\
\hline$\left|D E N S \_D I F F\right|$ & 100 & $0.12^{* * *}$ & 0.01 & 100 & $0.12^{\text {*** }}$ & 0.01 & 28 & 0.11 & 0.04 & 3 & 0.08 & 0.05 \\
\hline$\left|g d p \_D I F F\right|$ & 100 & $0.09^{* * *}$ & 0.01 & 6 & -0.04 & 0.02 & 100 & $-0.19^{* * *}$ & 0.03 & 100 & $-0.31^{* * *}$ & 0.04 \\
\hline BORDER $_{i j}$ & 100 & $0.42^{* * *}$ & 0.06 & 98 & $0.23^{* *}$ & 0.05 & & & & & & \\
\hline$I_{S L A N D_{i j}}$ & 100 & $-0.26^{* * *}$ & 0.02 & & & & & & & & & \\
\hline$L A N D L O C K_{i j}$ & 100 & $-0.20^{* * *}$ & 0.02 & & & & & & & & & \\
\hline $\log \left(A R E A_{i} A R E A_{j}\right)$ & 100 & $-0.13^{* * *}$ & 0.00 & & & & & & & & & \\
\hline REMOTE $_{i j t}$ & 100 & $0.81^{* * *}$ & 0.04 & & & & 0 & -0.01 & 0.02 & & & \\
\hline$C O L O N Y_{i j}$ & 100 & $1.19^{* * *}$ & 0.06 & 100 & $1.13^{* * *}$ & 0.06 & & & & & & \\
\hline $\mathrm{COMCOL}_{i j}$ & 100 & $0.27^{* * *}$ & 0.02 & 100 & $0.35^{* * *}$ & 0.04 & & & & & & \\
\hline$C O M L A N G_{i j}$ & 100 & $0.59^{* * *}$ & 0.04 & 100 & $0.30^{* * *}$ & 0.03 & & & & & & \\
\hline
\end{tabular}

Note: Fixed-effect coefficients are omitted. Asterisks represent weak, positive, and decisive evidence for an effect of the regressor, corresponding to posterior inclusion probabilities of $* 50-75 \%,{ }^{* *} 75-99$, and ${ }^{* * *}>99 \%$, respectively (see Jefferies, 1961; Kass and Raftery, 1995). $p \neq 0$ is the inclusion probability, $\mu$ is the posterior mean, and $\sigma$ is the posterior standard deviation.

American Integration Association (LAIA), magnitudes of significant PTA impacts are uniformly smaller when we explore only the specific effect of entering and exiting a trade agreement.

\subsection{A Comprehensive Approach}

The previous sections illustrated how each individual fixed-effect approach influences PTA estimates. In this section we present results from our most comprehensive approach, which controls for both unobserved heterogeneity and multilateral resistance simultaneously. The comprehensive 
approach adds a large number of fixed-effects controls to the regression, and is identical to the Baier and Bergstrand (2007) methodology. However, their focus was on the average PTA effect, while the motivation for this paper was to show the heterogeneity of trade effects across individual PTAs and to resolve model uncertainty. As outlined above, the comprehensive approach is also best suited to control for the various biases may be contained in a gravity equation, especially endogeneity bias.

Specification 6 in Table IV presents new results and presents a number of additional insights. Even after accounting for the large number of fixed effects, and after accounting for model uncertainty, a series of PTAs show strong effects on trade flows. CACM, CARICOM, EEA and LAIA all exhibit high inclusion probabilities and positive trade effects. The EU which oscillated from negative to positive coefficients is now economically significant but only marginally statistically significant. Note, however, that the EEA picks up important recent trade effects among a large number of EU members. We also find a dramatic reduction in predicted trade flows due to a PTA among the APEC countries. This is comforting since APEC did not institute actual tariff reductions, and it has been well known that the gravity models must have attributed some of the bilateral or individual country effects to the creation of APEC. Once we control for these effects, and for the potential endogenous selection of fast trade-growing countries into AFTA, we find that the actual affect of APEC is nil.

Among the non-PTA variables, only the difference in GDP remains significant. The coefficient indicates that countries with similar GDP generate larger trade volumes, which supports intraindustry trade theories rather than Heckscher-Ohlin. The variation of the results across different fixed effects raises the general question of integration dynamics. Are average estimates over the life of PTA membership appropriate, or can we observe accession dynamics where static effects (before or at accession) differ fundamentally from subsequent dynamic changes in trade flows? If we are interested in the specific effects of individual trade flows, there may well be accession dynamics in play that suggest that the simple averaging of effects over time may be misleading. We examine this hypothesis in the following section.

\subsection{Accession Dynamics}

Further investigation of accession dynamics may also yield benefits beyond the reconciliation of remaining differences between Specifications 4 and 5. Namely, accession dynamics provide insights whether gains from trade tend to be static, as advocated by neoclassical trade theory, or dynamic (e.g. Young 1991). Indeed the gain might even commence before the PTA accession. Hence we recode the PTA dummy into three separate effects. If accession occurs at time $t$, an accession dummy captures trade creation when the country joined a PTA, a pre-accession dummy captures the 5 years prior to joining a PTA $(t-1$ in our notation), and a post-accession dummy captures the 5 years following accession to the end of the sample, $(t+1, n)$, where $n$ indicates either the year 2000 or the year a country exited the PTA.

Results that include accession dynamics are presented in Table V, where we present specifications that control for multilateral resistance (Specification 4a), unobserved bilateral heterogeneity (Specification 5a), and for both of the former (Specification 6a). For expositional purposes, Table V does not report non-PTA regressors that were included in the analysis to save space. The posterior estimates and inclusion probabilities are very similar to the corresponding specifications without accession dynamics. Table $\mathrm{V}$ also includes the average PTA effects $(t, n)$ established in Specifications 4-6 to allow for quick comparisons between average effects and accession dynamics for each PTA.

The accession dynamics highlight the timing of the trade gains for each PTA. In general, the PTAs' effects on trade materialize in the accession and post-accession phases with the appropriate 
Table V. PTA accession dynamics

\begin{tabular}{|c|c|c|c|c|c|c|c|c|c|c|}
\hline \multicolumn{2}{|l|}{ Subramanian } & \multicolumn{3}{|c|}{$\begin{array}{c}\text { Specification } 4 \mathrm{a} \\
\text { Yes }\end{array}$} & \multicolumn{3}{|c|}{ Specification 5a } & \multicolumn{3}{|c|}{ Specification $6 \mathrm{a}$} \\
\hline \multicolumn{2}{|l|}{$\begin{array}{l}\text { Time fixed } \\
\text { effects }\end{array}$} & \multicolumn{3}{|c|}{ Yes } & \multicolumn{3}{|c|}{ Yes } & \multicolumn{3}{|c|}{ Yes } \\
\hline \multirow{4}{*}{$\begin{array}{l}\text { Imp. exp. fixed } \\
\text { effects } \\
\text { Country-pair fixed } \\
\text { effects } \\
\text { Accession } \\
\text { dynamics }\end{array}$} & & \multicolumn{3}{|c|}{ Yes } & \multicolumn{3}{|c|}{ No } & \multicolumn{3}{|c|}{ Yes } \\
\hline & & \multicolumn{3}{|c|}{ No } & & Yes & & & Yes & \\
\hline & & \multicolumn{3}{|c|}{ Yes } & \multicolumn{3}{|c|}{ Yes } & \multicolumn{3}{|c|}{ Yes } \\
\hline & & $p \neq 0$ & $\mu$ & $\sigma$ & $p \neq 0$ & $\mu$ & $\sigma$ & $p \neq 0$ & $\mu$ & $\sigma$ \\
\hline \multirow[t]{4}{*}{$A F T A_{i j t}$} & Average $(t, n)$ & 1 & -0.36 & 0.32 & 1 & 0.27 & 0.24 & 2 & -0.38 & 0.29 \\
\hline & $\begin{array}{l}\text { Pre-accession } \\
\quad(t-1)\end{array}$ & 0 & -0.26 & 0.34 & 1 & 0.00 & 0.07 & 0 & -0.36 & 0.32 \\
\hline & Accession $(t)$ & 0 & -0.43 & 0.41 & 0 & 0.00 & 0.02 & 0 & -0.54 & 0.36 \\
\hline & $\begin{array}{l}\text { Post-accession } \\
\quad(t+1, n)\end{array}$ & 0 & 0.00 & 0.00 & 1 & 0.01 & 0.07 & 0 & 0.00 & 0.00 \\
\hline \multirow[t]{4}{*}{ ANZCERTA $_{i j t}$} & Average $(t, n)$ & 94 & $2.15^{* *}$ & 0.56 & 0 & -0.02 & 0.51 & 3 & 0.89 & 0.60 \\
\hline & $\begin{array}{l}\text { Pre-accession } \\
\quad(t-1)\end{array}$ & 2 & 2.17 & 1.07 & 1 & 0.00 & 0.03 & 0 & 0.00 & 0.00 \\
\hline & Accession $(t)$ & 1 & 1.74 & 1.07 & 0 & 0.00 & 0.05 & 0 & 0.00 & 0.00 \\
\hline & $\begin{array}{l}\text { Post-accession } \\
(t+1, n)\end{array}$ & 66 & $2.12^{*}$ & 0.62 & 0 & 0.00 & 0.04 & 0 & 0.92 & 0.63 \\
\hline \multirow[t]{4}{*}{$A P E C_{i j t}$} & Average $(t, n)$ & 100 & $0.62^{* * *}$ & 0.09 & 100 & $0.52^{* * *}$ & 0.06 & 1 & 0.09 & 0.08 \\
\hline & $\begin{array}{l}\text { Pre-accession } \\
\quad(t-1)\end{array}$ & 100 & $0.74^{* * *}$ & 0.12 & 100 & $0.54^{* * *}$ & 0.08 & 10 & 0.23 & 0.11 \\
\hline & Accession $(t)$ & 100 & $0.75^{* * *}$ & 0.12 & 100 & $0.64^{* * *}$ & 0.08 & 21 & 0.24 & 0.11 \\
\hline & $\begin{array}{l}\text { Post-accession } \\
(t+1, n)\end{array}$ & 100 & $0.57^{* * *}$ & 0.11 & 100 & $0.66^{* * *}$ & 0.08 & 0 & -0.08 & 0.10 \\
\hline \multirow[t]{4}{*}{$A P_{i j t}$} & Average $(t, n)$ & 93 & $0.59^{* *}$ & 0.15 & 6 & 0.44 & 0.19 & 99 & $0.80^{* *}$ & 0.24 \\
\hline & $\begin{array}{l}\text { Pre-accession } \\
\quad(t-1)\end{array}$ & 2 & -0.65 & 0.32 & 0 & 0.00 & 0.02 & 0 & 0.00 & 0.00 \\
\hline & Accession $(t)$ & 0 & 0.00 & 0.00 & 2 & -0.01 & 0.07 & 0 & 0.00 & 0.00 \\
\hline & $\begin{array}{l}\text { Post-accession } \\
(t+1, n)\end{array}$ & 98 & $0.67^{* *}$ & 0.16 & 4 & 0.01 & 0.08 & 87 & $0.68^{* *}$ & 0.24 \\
\hline \multirow[t]{4}{*}{$C A C M_{i j t}$} & Average $(t, n)$ & 100 & $2.34^{* * *}$ & 0.14 & 100 & $2.19^{* * *}$ & 0.26 & 100 & $1.59^{* * *}$ & 0.37 \\
\hline & $\begin{array}{l}\text { Pre-accession } \\
\quad(t-1)\end{array}$ & 2 & -0.79 & 0.42 & 2 & -0.02 & 0.21 & 88 & $-1.6^{* *}$ & 0.38 \\
\hline & Accession $(t)$ & 2 & 0.79 & 0.39 & 100 & $1.85^{* * *}$ & 0.35 & 5 & 0.22 & 0.95 \\
\hline & $\begin{array}{l}\text { Post-accession } \\
(t+1, n)\end{array}$ & 100 & $2.52^{* * *}$ & 0.15 & 100 & $2.24^{* * *}$ & 0.27 & 15 & 1.14 & 0.43 \\
\hline \multirow[t]{4}{*}{ CARICOM $_{i j t}$} & Average $(t, n)$ & 100 & $4.27^{* * *}$ & 0.28 & 63 & $1.45^{*}$ & 0.43 & 92 & $1.59^{* *}$ & 0.53 \\
\hline & $\begin{array}{l}\text { Pre-accession } \\
\quad(t-1)\end{array}$ & 0 & 0.00 & 0.00 & 2 & -0.02 & 0.21 & 0 & -0.86 & 0.99 \\
\hline & Accession $(t)$ & 100 & $4.13^{* * *}$ & 0.42 & 2 & 0.02 & 0.17 & 4 & 1.43 & 0.59 \\
\hline & $\begin{array}{l}\text { Post-accession } \\
(t+1, n)\end{array}$ & 100 & $4.34^{* * *}$ & 0.35 & 2 & 0.02 & 0.14 & 7 & 1.32 & 0.69 \\
\hline \multirow[t]{4}{*}{$E E A_{i j t}$} & average $(t, n)$ & 99 & $0.49^{* *}$ & 0.12 & 25 & -0.24 & 0.08 & 100 & $0.49^{* * *}$ & 0.11 \\
\hline & $\begin{array}{l}\text { Pre-accession } \\
\quad(t-1)\end{array}$ & 1 & 0.20 & 0.14 & 92 & $0.34^{* *}$ & 0.13 & 5 & 0.24 & 0.12 \\
\hline & Accession $(t)$ & 1 & 0.26 & 0.14 & 11 & 0.03 & 0.08 & 42 & 0.29 & 0.12 \\
\hline & $\begin{array}{l}\text { Post-accession } \\
(t+1, n)\end{array}$ & 100 & $0.74^{* * *}$ & 0.14 & 30 & -0.10 & 0.16 & 100 & $0.69^{* * *}$ & 0.14 \\
\hline$E F T A_{i j t}$ & Average $(t, n)$ & 2 & -0.17 & 0.11 & 5 & 0.26 & 0.12 & 1 & -0.08 & 0.15 \\
\hline & $\begin{array}{l}\text { Pre-accession } \\
\quad(t-1)\end{array}$ & 3 & -0.64 & 0.30 & 1 & 0.00 & 0.03 & 0 & 0.00 & 0.00 \\
\hline & Accession $(t)$ & 0 & 0.00 & 0.00 & 1 & 0.00 & 0.01 & 0 & -0.28 & 0.21 \\
\hline & $\begin{array}{l}\text { Post-accession } \\
\quad(t+1, n)\end{array}$ & 1 & -0.17 & 0.12 & 30 & -0.10 & 0.16 & 0 & 0.00 & 0.00 \\
\hline
\end{tabular}


Table V. (Continued)

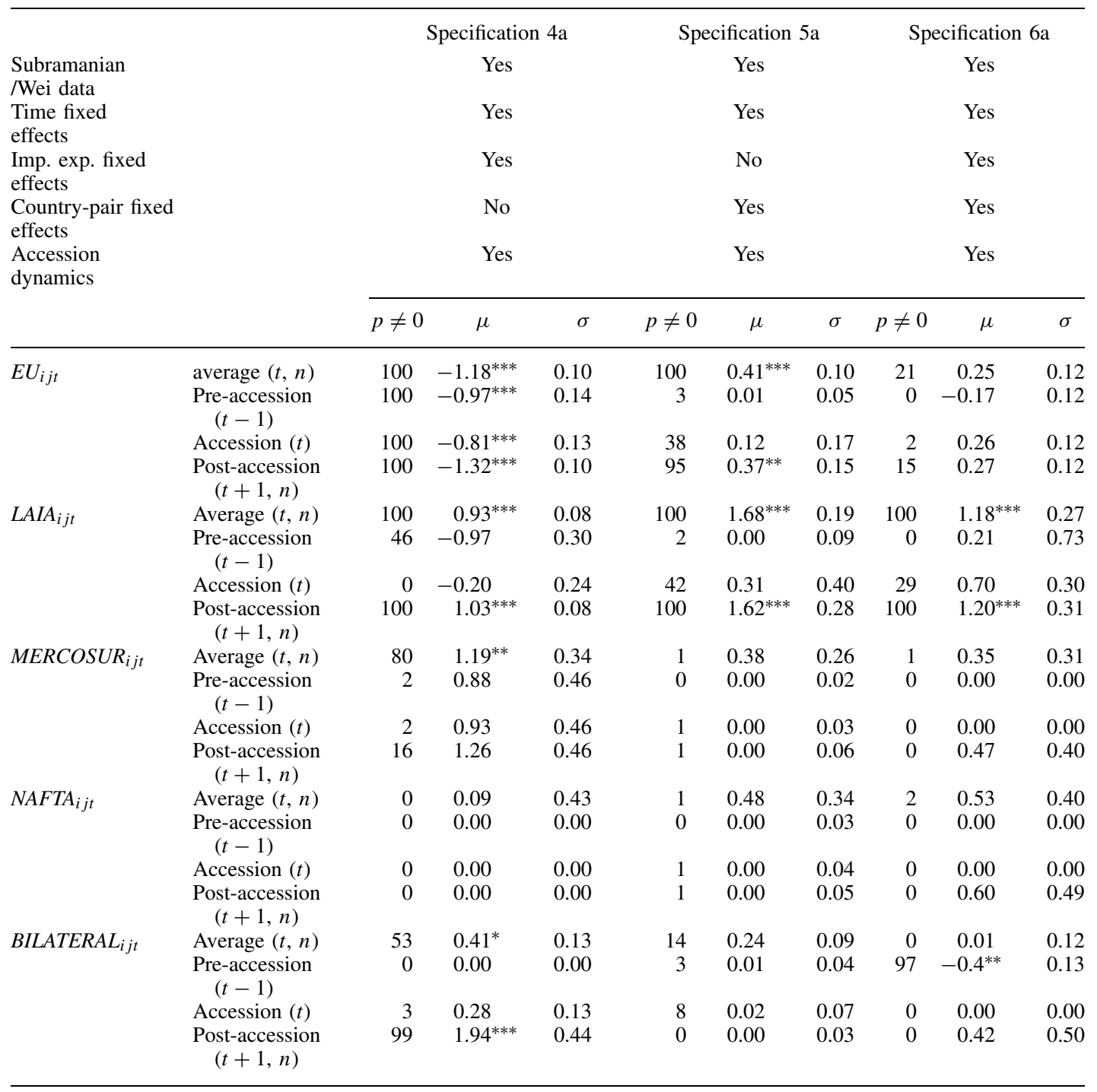

Note: Fixed-effect coefficients are omitted. Asterisks represent weak, positive, and decisive evidence for an effect of the regressor, corresponding to posterior inclusion probabilities of * 50-75\%, $* * 75-99$, and ${ }^{* * *}>99 \%$, respectively (see Jefferies, 1961; Kass and Raftery, 1995). $p \neq 0$ is the inclusion probability, $\mu$ is the posterior mean, and $\sigma$ is the posterior standard deviation.

magnitudes. The accession results also show a high coincidence between average effects and dynamic effects; namely only PTAs that produce average effects in Table IV also produce dynamic PTA effects in Table V. There are two interesting exceptions to this rule. In specification 6 , where we control for both country-pair and time-varying importer/exporter time fixed effects, we find that there is a gradual onset of trade creation for those PTAs with overall net trade creation. The Latin America Integration Association (LAIA) and the European Economic Area (EEA) illustrate that net trade creation first becomes notable in the accession period and fortifies thereafter. The patterns in the Central American Common Market (CACM) and bilateral trade agreements differ slightly. 
These PTAs show negative net trade creation pre-accession, which is remedied by accession to the PTA. PTA accession thus created trade, correcting for members' previously observed undertrade relative to the gravity prediction.

\subsection{Other Determinants of Trade Flows}

So far we have discussed only the impact of PTAs on trade flows. However, the BMA exercise holds important additional information regarding other determinants of trade flows. The geography and history controls are highly significant in Specifications 1 and 2 (in agreement with the previous literature). Althought the magnitues of their effects are reduced by the fixed effects, they generally remain significant.

BMA identifies trade openness as a key variable in all specifications, which is not surprising since we are attempting to explain trade flows. More interesting is that a number of variables related to exchange rate policy are not significant unless we control for bilateral unobservables. The currency union variable, on the other hand, shows a strong effect independent of dataset or empirical specification. Additional variables that might influence trade flows are factor endowments. Here BMA allows us to examine the competing hypotheses that trade flows are either driven by differences in endowments (Heckscher-Ohlin) or by similarities (Lindner). In Specifications 1 and 2, the Heckscher-Ohlin factor endowment theory finds strong support, as differences in per capita GDPs and population densities are strongly associated with greater trade flows. The endowment effect vanishes, however, when we consider multilateral resistance. Effects of population density disappear once we account for bilateral heterogeneity. Finally, the BMA methodology shows that differences in schooling increase bilateral trade flows when we control for either unobserved heterogeneity or multilateral resistance.

\section{CONCLUSION}

The literature on preferential trade agreements (PTAs) features an unusual diversity of theoretical and empirical approaches. In this paper we incorporate model uncertainty into the empirical strategy by applying Bayesian model averaging (BMA). To date, the most extensive robustness analysis by Ghosh and Yamarik (2004) used extreme bound analysis and found evidence against any effects of PTAs at the extreme bounds. In contrast, applying BMA to Ghosh and Yamark's original dataset we find that PTA trade creation is strong. In addition, the BMA approach produces coefficient estimates that resolve a number of empirical puzzles.

We confirm strong PTA effects not only with Ghosh and Yamarik's original dataset, but also with an updated dataset that includes additional years and PTAs. Our results are robust to the inclusion of multilateral resistance, accession dynamics, and unobserved bilateral heterogeneity. Overall, the observed PTA effects reflect the diversity of PTAs and the degree of tariff reductions they encompass. BMA allows us to also account for model uncertainty in the set of additional control variables usually featured in PTA regressions. Our approach highlights the importance of including all controls for policy, development, factor endowments, geography, and history that have been suggested by the previous literature. Among these regressors, the only ones that receive mixed evidence are those related to exchange rate fluctuations.

\section{ACKNOWLEDGEMENTS}

We thank the editor and four anonymous referees for many valuable comments and suggestions. We also thank Steven Yamarik for sharing his dataset and Serban Ranca for outstanding research 
assistance. Brian Donhauser and Alan van der Hilst provided helpful comments. Christian Henn acknowledges support from the Henry Buechel Memorial Fellowship. The views expressed in this study are the sole responsibility of the authors and should not be attributed to the International Monetary Fund, its Executive Board, or its management.

\section{REFERENCES}

Aitken ND. 1973. The effect of the EEC and EFTA on European trade: a temporal cross-section analysis. American Economic Review 63: 881-892.

Aitken ND, Lowry WR. 1973. A Cross-Sectional Study of the Effects of LASEAN and CACM on Latin American Trade. Journal of Common Market Studies 11(4): 326-336.

Anderson J, van Wincoop E. 2003. Gravity with gravitas: a solution to the border puzzle. American Economic Review 93: 170-192.

Andrews M, Schank T, Upward R. 2006. Practical fixed effects estimation methods for the three-way error components model. Stata Journal 6: 461-481.

Anselin L, Griffith DA. 1988. Do spatial effects really matter in regression analysis? Papers, Regional Science Association 65: 11-34.

Baier SL, Bergstrand JH. 2002. On the endogeneity of international trade flows and free trade agreements. Manuscript, University of Notre Dame.

Baier SL, Bergstrand JH. 2004a. Do free trade agreements actually increase members' international trade? Manuscript, University of Notre Dame.

Baier SL, Bergstrand JH. 2004b. Economic determinants of free trade agreements. Journal of International Economics 64: 29-63.

Baier SL, Bergstrand JH. 2007. Do free trade agreements actually increase members' international trade? Journal of International Economics 71: 72-95.

Baier SL, Bergstrand JH, Egger P, McLaughlin PA. 2008. Do economic integration agreements actually work? Issues in understanding the causes and consequences of the growth of regionalism. The World Economy 31: 461-497.

Baldwin R. 2005. The Euro's trade effects. Working paper prepared for ECB Workshop, 'What Effects is EMU Having on the Euro Area and its Member Countries?' Frankfurt, 16 June 2005.

Baldwin R, Taglioni D. 2006. Gravity for dummies and dummies for gravity equations. NBER Working Paper No. 12516.

Baltagi BH, Egger P, Pfaffermayr M. 2007. Estimating models of complex FDI: are there third-country effects? Journal of Econometrics 140(1): 260-281.

Barro R, Lee JW. 2001. International data on educational attainment: updates and implications. Oxford Economic Papers 53: 541-563.

Baxter M, Kouparitsas MA. 2006. What determines bilateral trade flows? NBER Working Paper No. 12188.

Bergstrand J. 1985. The gravity equation in international trade: some microeconomic foundation and empirical evidence. Review of Economics and Statistics 67: 474-481.

Bhagwati J, Panagariya A. 1996. Preferential trading areas and multilateralism: strangers, friends or foes? In The Economics of Preferential Trade Agreements, Bhagwati J, Panagariya A (eds). AEI Press: Washington, DC; $1-78$.

Bond EW, Syropoulos C. 1996. The size of trading blocs, market power and world welfare effects. Journal of International Economics 40: 411-437.

Bougheas S, Demetriades P, Morgenroth E. 2003. International aspects of public infrastructure investment. Canadian Journal of Economics 36(4): 884-910.

Brada JC, Méndez JA. 1988. Exchange Rate Risk, Exchange Rate Regime and the Volume of International Trade. Kyklos 41(2): 263-280.

Brock W, Durlauf SN, West K. 2003. Policy evaluation in uncertain economic environments. Brookings Papers on Economic Activity 1: 235-322.

Carrere C. 2006. Revisiting the effects of regional trade agreements on trade flows with proper specification of the gravity model. European Economic Review 50: 223-247.

Chen YC, Rogoff K. 2006. Commodity currencies and exchange rate predictability: a Bayesian model averaging approach. Working paper, University of Washington.

Cheng I, Wall HJ. 2005. Controlling for heterogeneity in gravity models of trade and integration. Federal Reserve Bank of St Louis Review 87: 49-63. 
Clark P, Tamirisa N, Wei SJ, Sadikov A, Zeng L. 2004. Exchange rate volatility and trade flows: some new evidence. Working paper, International Monetary Fund.

Coe DT, Hoffmaister AW. 1999. North-South Trade: Is Africa Unusual. Journal of African Economies 8(2): $228-256$.

Davis DR. 1995. Intra-industry trade: a Heckscher-Ohlin-Ricardo approach. Journal of International Economics 39: 201-226.

Deardorff AV. 1998. Determinants of bilateral trade: does gravity work in a classical world. In The Preferentialization of the World Economy, Frankel J (ed.). University of Chicago Press: Chicago, IL; 7-22.

Deardorff AV, Stern R. 1994. Multilateral trade negotiations and preferential trade agreements. In Analytical and Negotiating Issues in the Global Trading System, Deardorff AV, Stern R (eds). University of Michigan Press: Ann Arbor, MI; 27-94.

Doppelhofer G, Weeks M. 2009. Jointness of growth determinants. Journal of Applied Econometrics 24: 209-244.

Eichengreen B, Irwin DA. 1996. The Role of History in Bilateral Trade Flows (Working Paper No. 5565). Cambridge, MA: National Bureau of Economic Research.

Eicher TS, Papageorgiou C, Raftery AE. 2010. Determining growth determinants: default priors and predictive performance in Bayesian model averaging. Journal of Applied Econometrics (forthcoming).

Egger P. 2000. A note on the proper econometric specification of the gravity equation. Economics Letters 66: $25-31$.

Egger P. 2004. Estimating regional trading bloc effects with panel data. Review of World Economics 140(1): $151-166$.

Egger P, Pfaffermayr M. 2003. The proper panel econometric specification of the gravity equation: a threeway model with bilateral interaction effects. Empirical Economics 28: 571-580.

Feenstra RC, Markusen JR, Rose AK. 2001. Using the gravity equation to differentiate among alternative theories of trade. Canadian Journal of Economics 34: 430-477.

Felbermayr G, Kohler W. 2006. Exploring the intensive and extensive margins of world trade. Review of World Economics 142: 642-674.

Fernandez C, Ley E, Steel M. 2001. Model uncertainty in cross-country growth regressions. Journal of Applied Econometrics 16: 563-576.

Frankel J. 1992. Is Japan creating a yen bloc in East Asia and the Pacific? NBER Working Paper No. 4050.

Frankel J. 1997. Preferential Trading Blocs in the World Trading System. Institute for International Economics: Washington, DC.

Frankel J, Romer D. 1999. Does trade cause growth? American Economic Review 89: 379-399.

Frankel J, Rose AK. 1998. The endogeneity of the optimum currency area criteria. Economic Journal 108: 1009-1025.

Frankel J, Rose AK. 2002. An estimate of the effect of common currencies on trade and income. Quarterly Journal of Economics 117: 437-466.

Frankel J, Wei SJ. 1993. Trading blocs and currency blocs. NBER Working Paper No. 4335.

Frankel J, Wei SJ. 1996. ASEAN in a regional perspective. Pacific Basin Working Paper No. PB96-02.

Frankel J, Stein E, Wei SJ. 1995. Trading blocs and the Americas: the natural, the unnatural and the supernatural? Journal of Development Economics 47: 61-95.

Frankel J, Stein E, Wei SJ. 1997. Regional Trading Blocs in the World Economic System. Institute for International Economics: Washington, DC.

Freund C. 2000. Different paths from free trade: the gains from regionalism. Quarterly Journal of Economics 115: $1317-1341$.

Freund C, McLaren J. 1999. On the dynamics of trade diversion: evidence from four trade blocs. International Finance Discussion Paper 637, Board of Governors of the Federal Reserve System, Washington, DC.

Garratt A, Lee K, Pesaran MH, Shin Y. 2003. A long run structural macroeconometric model of the UK. Economic Journal 113: 412-455.

Ghosh S, Yamarik S. 2004. Are preferential trade agreements trade creating? An application of extreme bounds analysis. Journal of International Economics 63: 369-395.

Glick R, Rose AK. 2002. Does a currency union affect trade? The time-series evidence. European Economic Review 46(6): 1125-1151.

Grossman GM, Helpman E. 1991. Innovation and Growth in the Global Economy. MIT Press: Cambridge, MA.

Hausman JA, Taylor WE. 1981. Panel data and unobservable individual effects. Econometrica 49: 1377-1398.

Helpman E, Krugman PR. 1985. Market Structure and Foreign Trade. MIT Press: Cambridge, MA. 
Helpman E, Melitz MJ, Rubinstein Y. 2008. Estimating trade flows: trading partners and trading volumes. Quarterly Journal of Economics 123: 441-487.

Hummels D, Levinsohn J. 1995. Monopolistic competition and international trade: reconsidering the evidence. Quarterly Journal of Economics 110: 799-836.

Jeffries H. 1961. Theory of Probability (3rd edn). Clarendon Press: Oxford.

Kass RE, Raftery AE. 1995. Bayes factors. Journal of the American Statistical Association 90: 773-795.

Krugman P. 1991a. Is bilateralism bad? In International Trade and Trade Policy, Helpman E, Razin A (eds). MIT Press: Cambridge, MA; 9-23.

Krugman P. 1991b. The move toward free trade zones. In Policy Implications of Trade and Currency Zones, symposium sponsored by Federal Reserve Bank of Kansas City, Jackson Hole, WY, August; 7-42.

Leamer EE. 1983. Let's take the con out of econometrics. American Economic Review 73: 31-43.

Lee J, Swagel P. 1997. Trade barriers and trade flows across countries and industries. Review of Economics and Statistics 79: 372-382.

Levin A, Williams J. 2003. Robust monetary policy with competing reference models. Journal of Monetary Economics 50: 945-975.

Ley E, Steel MFJ. 2009. On the effect of prior assumptions in BMA with applications to growth regression. Journal of Applied Econometrics 24: 651-674.

Linder SB. 1961. An Essay on Trade and Transformation. Wiley: New York.

Magee C. 2003. Endogenous preferential trade agreements: an empirical analysis. Contributions to economic analysis and Policy 2(1): article 15.

Martin W, Pham CS. 2008. Estimating the gravity model when zero trade flows are frequent. Working paper, University of Melbourne.

Montenegro CE, Soto R. 1996. How Distorted is Cuba's Trade? Evidence and Predictions from a Gravity Model. Journal of International Trade and Economic Development 5(1): 45-70.

Novy D. 2006. Is the iceberg melting less quickly? International trade costs after World War II. Working paper, University of Warwick.

Novy D. 2007. Gravity Redux: measuring international trade costs with panel data. Working paper, University of Warwick.

Panagariya A. 1999. The regionalism debate: an overview. World Economy 22: 280-301.

Panagariya A. 2000. Preferential trade liberalization: the traditional theory and new developments. Journal of Economic Literature 38: 287-331.

Pesaran MH. 2006. Estimation and inference in large heterogeneous panels with a multifactor error structure. Econometrica 74: 967-1012.

Raftery AE, Zheng Y. 2003. Discussion: performance of Bayesian model averaging. Journal of the American Statistical Association: Theory and Methods 98: 931-938.

Raftery AE, Madigan D, Hoeting JA. 1997. Bayesian model averaging for linear regression models. Journal of the American Statistical Association 92: 179-191.

Rivera-Batiz LA, Romer PM. 1991. Economic integration and endogenous growth. Quarterly Journal of Economics 106: 531-555.

Rose AK. 2000. One money, one market? The effects of common currencies on international trade. Economic Policy 15: 7-46.

Rose AK. 2004. Do we really know that the WTO increases trade? American Economic Review 94: $98-114$.

Rose AK. 2005. Which international institutions promote international trade? Review of International Economics 13: 682-698.

Rose AK, van Wincoop E. 2001. National money as a barrier to international trade: the real case for a currency union. American Economic Review 91: 386-390.

Sachs J, Warner A. 1995. Economic reform and the process of global integration. Brookings Papers on Economic Activity 1: 1-118.

Sala-i-Martin XG. 1997. I just ran two million regressions. American Economic Review, Papers and Proceedings 87: 178-183.

Santos Silva JMC, Tenreyro S. 2006. The log of gravity. Review of Economics and Statistics 88(4): $641-658$.

Serlenga L, Shin Y. 2007. Gravity models of intra-EU trade: application of the CCEP-HT estimation in heterogeneous panels with unobserved common time-specific factors. Journal of Applied Econometrics 22: $361-381$.

Soloaga I, Winters LA. 2001. Regionalism in the nineties: what effect on trade? North American Journal of Economics and Finance 12(1): 1-29.

Spilimbergo A, Stein E. 1998. The welfare implications of trading blocs among countries with different endowments. In NBER Conference, Frankel J, Stein E (eds). University of Chicago Press: Chicago, IL. 
Subramanian A, Wei SJ. 2007. The WTO promotes trade, strongly but unevenly. Journal of International Economics 72: 151-175.

Tenreyro S, Barro RJ. 2007. Economic effects of currency unions. Economic Inquiry 45: 1-23.

Trefler D. 1993. International factor price differences: Leontief was right! Journal of Political Economy 101: 961-987.

Viner J. 1950. The Customs Union Issue. Carnegie Endowment for International Peace: New York.

Wacziarg R, Welch KH. 2003. Trade Liberalization and Growth: New Evidence (NBER Working Papers 10152). Cambridge, MA: National Bureau of Economic Research.

Wei S-J. 1996. Intra-national versus international trade: how stubborn are nations in global integration? (NBER Working Paper No. 5531). Cambridge, MA: National Bureau of Economic Research.

Wei S-J, Frankel J. 1998. Open regionalism in world of continental trades. IMF Staff Papers 45: 440-453.

Wei S-J \& Zhang Z, 2007. "Collateral damage: Exchange controls and international trade," Journal of International Money and Finance 26(5): 841-863.

Wooldridge JM. 2002. Econometric Analysis of Cross-Section and Panel Data. MIT Press: Cambridge, MA.

Young A. 1991. Learning by doing and the dynamic effects of international trade. Quarterly Journal of Economics 106: 369-405. 